Atmos. Chem. Phys., 13, 9819-9835, 2013

www.atmos-chem-phys.net/13/9819/2013/

doi:10.5194/acp-13-9819-2013

(c) Author(s) 2013. CC Attribution 3.0 License.

\title{
Hygroscopic properties of smoke-generated organic aerosol particles emitted in the marine atmosphere
}

\author{
A. Wonaschütz ${ }^{1}$, M. Coggon ${ }^{2}$, A. Sorooshian ${ }^{3,4}$, R. Modini $^{5, *}$, A. A. Frossard ${ }^{5}$, L. Ahlm ${ }^{5, *}$, J. Mülmenstädt $^{5}$, \\ G. C. Roberts ${ }^{5,6}$, L. M. Russell ${ }^{5}$, S. Dey ${ }^{7}$, F. J. Brechtel ${ }^{7}$, and J. H. Seinfeld ${ }^{2}$ \\ ${ }^{1}$ University of Vienna, Faculty of Physics, Vienna, Austria \\ ${ }^{2}$ Department of Chemical Engineering, California Institute of Technology, Pasadena, California, USA \\ ${ }^{3}$ Department of Chemical and Environmental Engineering, University of Arizona, Tucson, AZ, USA \\ ${ }^{4}$ Department of Atmospheric Sciences, University of Arizona, Tucson, AZ, USA \\ ${ }^{5}$ Scripps Institution of Oceanography, University of California, San Diego, CA, USA \\ ${ }^{6}$ Centre National de la Recherche Scientifique - Groupe d'études de l'Atmosphère Météorologique, Toulouse, France \\ ${ }^{7}$ Brechtel Manufacturing, Inc., Hayward, CA, USA \\ * now at: Ecole Polytechnique Federale de Lausanne, Lausanne, Switzerland \\ ***now at: Department of Applied Environmental Science, Stockholm University, Stockholm, Sweden
}

Correspondence to: A. Sorooshian (armin@email.arizona.edu)

Received: 15 April 2013 - Published in Atmos. Chem. Phys. Discuss.: 6 May 2013

Revised: 12 August 2013 - Accepted: 13 August 2013 - Published: 7 October 2013

\begin{abstract}
During the Eastern Pacific Emitted Aerosol Cloud Experiment (E-PEACE), a plume of organic aerosol was produced by a smoke generator and emitted into the marine atmosphere from aboard the R/V Point Sur. In this study, the hygroscopic properties and the chemical composition of the plume were studied at plume ages between 0 and $4 \mathrm{~h}$ in different meteorological conditions. In sunny conditions, the plume particles had very low hygroscopic growth factors (GFs): between 1.05 and 1.09 for $30 \mathrm{~nm}$ and between 1.02 and 1.1 for $150 \mathrm{~nm}$ dry size at a relative humidity (RH) of $92 \%$, contrasted by an average marine background GF of 1.6. New particles were produced in large quantities (several $10000 \mathrm{~cm}^{-3}$ ), which lead to substantially increased cloud condensation nuclei $(\mathrm{CCN})$ concentrations at supersaturations between 0.07 and $0.88 \%$. Ratios of oxygen to carbon $(\mathrm{O}: \mathrm{C})$ and water-soluble organic mass (WSOM) increased with plume age: from $<0.001$ to 0.2 , and from 2.42 to $4.96 \mu \mathrm{g} \mathrm{m}^{-3}$, respectively, while organic mass fractions decreased slightly $(\sim 0.97$ to $\sim 0.94)$. High-resolution aerosol mass spectrometer (AMS) spectra show that the organic fragment $m / z 43$ was dominated by $\mathrm{C}_{2} \mathrm{H}_{3} \mathrm{O}^{+}$in the small, new particle mode and by $\mathrm{C}_{3} \mathrm{H}_{7}^{+}$in the large particle mode. In the marine background aerosol, GFs for $150 \mathrm{~nm}$ particles at $40 \% \mathrm{RH}$ were found to be enhanced at higher organic mass
\end{abstract}

fractions: an average GF of 1.06 was observed for aerosols with an organic mass fraction of 0.53 , and a GF of 1.04 for an organic mass fraction of 0.35 .

\section{Introduction}

The interaction of atmospheric aerosol particles with water is a crucial factor affecting their evolution in the atmosphere. By taking up water, particles grow in size and experience modifications to their refractive index, which changes their ability to interact with solar radiation. Activation into cloud droplets is a determining factor in the atmospheric lifetime of particles. Furthermore, cloud droplets and water in deliquesced aerosol particles provide an aqueous medium for chemical reactions, which can lead to a change in the chemical composition of the particles (Hegg, 1985; Blando and Turpin, 2000; El Haddad et al., 2009; Bateman et al., 2011; Ervens et al., 2011).

Organic compounds can have a profound impact on the water-uptake properties of particles. An increase in the organic mass fraction of aerosol particles can reduce water uptake at relative humidities ( $\mathrm{RH})$ above the deliquescence $\mathrm{RH}$ (DRH) of salts, while simultaneously enabling hygroscopic 
growth at RHs below the DRH (e.g., Dick et al., 2000; Hersey et al., 2009; Meyer et al., 2009). In the atmosphere, aging processes affect hygroscopic properties of the organic fraction of aerosols (commonly referred to as organic aerosols, OA). Organic components in fresh aerosols have been observed to decrease water uptake, but in aged aerosols, they can have the opposite effect (Saxena et al., 1995). Aging of aerosols broadly encompasses any change in their chemical composition and physical properties during their lifetime in the atmosphere. For OA, important aging processes include the addition of organic mass through secondary production via gas-to-particle conversion and aqueous-phase production (e.g., George et al., 2007; El Haddad et al., 2009; Ervens et al., 2011), as well as the continuing oxidation during photochemical and cloud processing (Jimenez et al., 2009). The transition from less oxidized to more oxidized organic compounds in $\mathrm{OA}$ increases hygroscopic growth factors $(\mathrm{GF}=$ $d_{\mathrm{p}, \mathrm{RH}} / d_{\mathrm{p}, \mathrm{dry}}$ ) (Massoli et al., 2010; Duplissy et al., 2011). The conversion of hydrophobic primary OA to hydrophilic particles has been shown to be rapid during the daytime in an urban environment (Wang et al., 2010).

Hygroscopic growth and cloud condensation nuclei (CCN) activity are often described in terms of a single parameter connecting the hygroscopicity of particles in the sub- and the supersaturated regime (Petters and Kreidenweis, 2007; Wex et al., 2008; Dusek et al., 2011). However, observations of several aerosol types, including biomass burning aerosol (Petters et al., 2009; Dusek et al., 2011), laboratorygenerated secondary organic aerosol (SOA) (Wex et al., 2009), primary marine organic aerosol (Ovadnevaite et al., 2011a), and urban ambient aerosol (Hersey et al., 2013), have shown conflicting behavior in the form of reduced hygroscopic growth factors with simultaneous enhancements in $\mathrm{CCN}$ activity. The role of organic compounds in changing water-uptake properties of aerosols is not fully understood.

The marine environment is well suited to study the aging of organic aerosols. In continental locations, with numerous anthropogenic and natural aerosol sources, fresh and aged organic aerosols are often found in the same air mass. Over the ocean, sources of organic aerosols are more limited. Continental outflow is often the most important source of OA (Hawkins et al., 2010); however, primary and secondary marine sources can be relevant (Gantt and Meskhidze, 2013). An important marine primary organic aerosol source is bubble bursting, which transfers dissolved or film-forming organic substances from the ocean surface into the particle phase in the atmosphere (e.g., Middlebrook et al., 1998; O'Dowd et al., 2004; Cavalli et al., 2004; Leck and Bigg, 2005; Facchini et al., 2008a; Russell et al., 2010; Modini et al., 2010; Ovadnevaite et al., 2011b). Proposed marine sources of SOA include biogenic amines (Facchini et al., 2008b; Sorooshian et al., 2009; Dall'Osto et al., 2012), isoprene oxidation above phytoplankton blooms (Meskhidze and Nenes, 2006; O'Dowd and de Leeuw, 2007), and aqueous-phase production in marine stratus clouds (Cra- han et al., 2004; Sorooshian et al., 2010). In the absence of such sources, marine background aerosol typically shows a hygroscopic mode with growth factors around 1.6-1.79 at $90 \%$ RH (Swietlicki et al., 2008, and references therein). Less hygroscopic and hydrophobic modes are encountered in continental outflow (e.g., Hawkins et al., 2010; Hegg et al., 2010), free tropospheric air masses, and during episodes of fresh biogenic aerosol production (Swietlicki et al., 2008; Allan et al., 2009; Hersey et al., 2009; Mochida et al., 2011). Hygroscopic growth factors and the activation ratio (the ratio of $\mathrm{CCN}$ at a given supersaturation to the total measured particle number concentration, $\mathrm{CCN} / \mathrm{CN}$ ) have been shown to increase with the age of the continental air mass (Massling et al., 2007; Furutani et al., 2008). Anthropogenic disturbances such as emissions from ship traffic and oil spills constitute further sources of organic aerosols in the marine atmosphere. The injection of container ship exhaust, which includes particles consisting of a mix of hydrocarbon-like organic aerosol and sulfate (Murphy et al., 2009), is a persistent anthropogenic impact on atmospheric composition (Eyring et al., 2009). During the Deepwater Horizon oil spill, hydrocarbonlike SOA was found to derive from intermediate volatility organic compounds evaporated from the oil surface (de Gouw et al., 2011). Most of these particles acted as CCN at supersaturations exceeding $0.3 \%$, but were characterized by low hygroscopicity in the subsaturated regime (Moore et al., 2012).

This study aims to improve the process-level understanding of changes in water-uptake properties of organic aerosol by investigating a rare "hybrid experiment" between laboratory and field conditions: a well-defined organic aerosol is artificially generated in large quantities and exposed to the real marine atmosphere. We report measurements of hygroscopic growth factors and $\mathrm{CCN}$ concentrations in this organic plume, and compare its aging and its hygroscopic properties in both cloudy and sunny conditions.

\section{Methods}

\subsection{The E-PEACE field campaign}

The Eastern Pacific Emitted Aerosol Cloud Experiment (EPEACE) was a field campaign conducted off the coast of California in July and August of 2011. Its general aim was to study aerosol-cloud-radiation interactions through the controlled emission of known aerosols into the marine stratocumulus deck and the measurement of its effects from ship, aircraft, and satellite observational platforms. A detailed description of the experiment and its first results are given by Russell et al. (2013). The location of the experiment is shown in Fig. 1. In this study, we investigate an organic plume produced on and emitted from the R/V Point Sur on a 12-day research cruise (12-23 July). To create the plume, refurbished battleship smoke generators were operated at the ship's stern: 


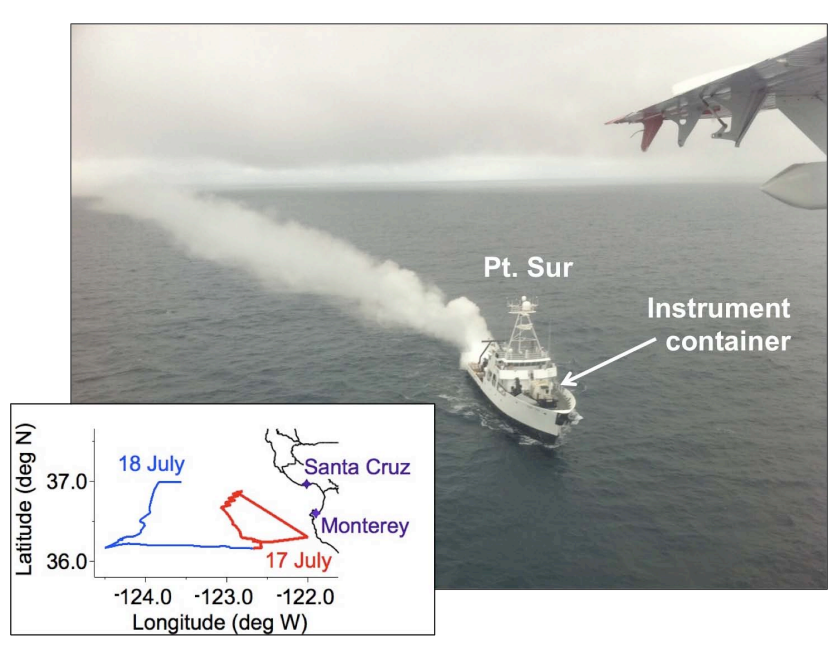

Fig. 1. Smoke generation on the R/V Point Sur (photo taken from CIRPAS Twin Otter). Insert: General area of the E-PEACE field campaign off the coast of California. The ship's course is shown for the days that are the focus of this study.

pulse jet engines operated with standard gasoline pumped and heated a paraffin-type oil, which vaporized at a temperature of about $150^{\circ} \mathrm{C}$, without igniting. Upon emission into the marine atmosphere through three nozzles, the oil condensed into a thick smoke of oil droplets and vapor ("organic plume", Fig. 1). More details on the oil production can be found in Russell et al. (2013). The properties of the organic plume and its interactions with the marine environment were measured from two platforms: the Center for Interdisciplinary Remotely-Piloted Aircraft Studies (CIRPAS) Twin Otter aircraft, and an instrument container on the R/V Point Sur itself. This study focuses on measurements from the R/V Point Sur.

\subsection{Instruments}

A complete list of all instruments located on the two platforms is given by Russell et al. (2013). The instruments onboard the R/V Point Sur whose data are used for this study are summarized in Table 1. The R/V Point Sur instrument container was located at the ship's bow. A common vertical inlet, which was shielded from spray, sampled ambient aerosol up to several micrometers in diameter. The aerosol was dried in diffusion driers before distribution to the instruments. Submicrometer particle size distributions were measured with a scanning electrical mobility spectrometer (SEMS Model 138 2002, Brechtel Manufacturing Inc.). Size distributions of larger particles were measured with an aerodynamic particle sizer (APS 3321, TSI Inc., size range 0.5$20 \mu \mathrm{m}$ ) and an optical particle sizer (OPS 330, TSI Inc., size range $0.3-10 \mu \mathrm{m})$. A condensation particle counter (CPC 3010, TSI Inc.) measured total particle number concentration.
Hygroscopic growth factors were measured using a humidified tandem differential mobility analyzer (HTDMA Model 3002, Brechtel Manufacturing Inc.) (Sorooshian et al., 2012). The system consisted of a dry DMA (DMA 1, $\mathrm{RH}<8 \%$ ) selecting particles with dry diameters of 30,75 , 150 , and $300 \mathrm{~nm}$; a humidifier, in which the dry particles were exposed to RHs of $40,70,85$, and $92 \%$; and a second, humidified DMA (DMA 2), which measured the number size distribution after hygroscopic growth. $\mathrm{CCN}$ concentrations for supersaturations $(S)$ ranging between 0.07 and $0.88 \%$ were measured using a $\mathrm{CCN}$ counter (custom design, miniaturized after Roberts and Nenes, 2005).

Submicrometer particles, separated from larger particles with a cyclone, were analyzed with a high-resolution timeof-flight aerosol mass spectrometer (AMS, Aerodyne Research Inc.) (DeCarlo et al., 2006) to measure the nonrefractory, inorganic (ammonium, sulfate, nitrate, chloride), and organic chemical composition. Submicrometer particles were also collected on $37 \mathrm{~mm}$ Teflon filters and scanned using Fourier transform infrared (FTIR) spectroscopy (Tensor 27, Bruker Optics, Inc.) (Russell et al., 2009; Frossard and Russell, 2012). I addition, samples of the ship diesel and smoke oil that were used during the E-PEACE cruise were atomized (atomizer, TSI Inc.), collected on Teflon filters, and scanned using FTIR spectroscopy.

Water-soluble organic carbon (WSOC) mass concentrations were quantified with a particle-into-liquid sampler (PILS, Brechtel Manufacturing Inc.) coupled to a total organic carbon analyzer (Sievers, Model 800) (Sullivan et al., 2006; Wonaschuetz et al., 2011). Black carbon (BC) concentrations were obtained from a single-particle soot photometer (SP2, Droplet Measurement Technologies Inc.). Meteorological conditions, including ambient temperature, wind direction and speed (corrected for the ship's movement), and RH, were measured routinely on the R/V Point Sur, along with ship-specific data such as heading and speed. Additional visual observations (e.g., fog, other ships) were noted in deck logs.

Mass concentrations of oxalate and glyoxylate are reported in this work for the smoke-sampling events (described in Sect. 2.6). $\mathrm{PM}_{10}$ was collected on prebaked $47 \mathrm{~mm}$ quartz fiber filters that were stored in a freezer prior to chemical analysis. The filter extraction procedure consisted of ultrasonication $(15 \mathrm{~min}$ ) of filter halves with $18.2 \mathrm{M} \Omega$ Milli-Q water. Syringe filters (Acrodisc filter, $25 \mu \mathrm{m}$ ) were used to remove any remaining insoluble matter from the extracts after ultrasonication. Ion chromatography analysis (IC - Thermo Scientific Dionex ICS-5000 anion system with an AS11-HC $2 \mathrm{~mm}$ column) was conducted using a $38 \mathrm{~min}$ multi-step gradient program with sodium hydroxide eluent $(1 \mathrm{mM}$ from 0 to $8 \mathrm{~min}, 1 \mathrm{mM}$ to $30 \mathrm{mM}$ from 8 to $28 \mathrm{~min}, 30 \mathrm{mM}$ to $60 \mathrm{mM}$ from 28 to $38 \mathrm{~min}$ ). 
Table 1. Instruments on the R/V Point Sur.

\begin{tabular}{llll}
\hline Measurement & Instrument & Size range & Time resolution \\
\hline Particle size distribution & APS & $0.5-20 \mu \mathrm{m}$ & $2 \mathrm{~min}$ \\
& OPS & $0.3-50 \mu \mathrm{m}$ & $2 \mathrm{~min}$ \\
& SEMS & $10-946 \mathrm{~nm}$ & $5 \mathrm{~min}$ \\
\hline \multirow{2}{*}{ Number concentration } & CPC & $>10 \mathrm{~nm}$ & $1 \mathrm{~s}$ \\
\hline \multirow{2}{*}{ Water uptake } & CCN counter & & $9 \mathrm{~s}$ \\
& HTDMA (hygroscopic growth) & $30,75,150,300 \mathrm{~nm}$ & $\sim 5 \mathrm{~min}$ \\
\hline \multirow{2}{*}{ Chemical composition } & AMS & $<1 \mu \mathrm{m}$ & $4 \mathrm{~min}$ \\
& PILS - TOC (water-soluble organic carbon) & $<1 \mu \mathrm{m}$ & $6 \mathrm{~min}$ \\
& SP2 (black carbon) & $80-300 \mathrm{~nm}$ & $10 \mathrm{~s}$ \\
& Filters scanned with FTIR spectroscopy & $<1 \mu \mathrm{m}$ & $20 \mathrm{~min}-4 \mathrm{~h}$ \\
\hline
\end{tabular}

\subsection{Data processing and quality control}

For the HTDMA data, an important source of uncertainty is the variability of RH in DMA 2 (Swietlicki et al., 2008). For quality control, temperature and RH in DMA 2 and their variability in time (over the duration of a scan) and space (along the DMA 2 column) were calculated from measurements of flow rates, temperatures, and $\mathrm{RH}$ in the sample flow out of the humidifier and the sheath flow in DMA 2 at the beginning of the DMA 2 column (these two flows were humidified separately), and of temperature in the excess flow at the end of the DMA 2 column. Scans were accepted if they fulfilled the following criteria: (i) flow rates were within $25 \%$ of the set point, (ii) combined humidifier and sheath air RH variability over the time of a scan did not exceed $\pm 1.5 \%$ $\mathrm{RH}$, and (iii) the temperature gradient over the length of the DMA 2 did not exceed $\pm 1{ }^{\circ} \mathrm{C}$. Based on these criteria, $75 \%$ of all scans were accepted. The raw count data from DMA 2 were inverted to produce the growth factor distributions: raw counts were shifted in time to correct for particle transit time between the DMA column and particle counter and desmeared to correct for a finite particle counter response time. The desmeared data were finally inverted using the diffusing form of the DMA transfer function (Stolzenburg, 1988) and assuming a single charge. Correcting only for a single charge (i.e., inverting for DMA 2 only, rather than the combined TDMA system) will accurately recover GF values and the relative fractions of growth factor populations, with some limitations on the resolution of the distribution shape (Gysel et al., 2009). Growth factors were estimated by fitting a lognormal function to the growth factor distributions, assuming mono-modal distributions as a first-order estimate and advancing to multi-peak fits when needed (Sect. 3.5).

The GF uncertainty was estimated using modeled GF values for selected inorganic salts (ammonium sulfate and sodium chloride) and malonic acid from a thermodynamic model of particle water uptake (Brechtel and Kreidenweis, 2000a, b; Sorooshian et al., 2008). Over the course of the HT-
DMA measurements, the change in mean RH in DMA 2 from one scan to the next rarely exceeded $1 \%$ RH. The measurement GF uncertainty was therefore estimated by calculating the change in GF for a change in RH of $1 \%(\mathrm{RH})$ around the set-point RH for pure particles of the three model substances. The maximum GF uncertainty for a RH set point of $40 \%$ is estimated to be 0.010 (malonic acid particles; the RH set point of $40 \%$ is below the efflorescence point for ammonium sulfate and sodium chloride). For the RH set point of $92 \%$, the maximum GF uncertainty is 0.185 (sodium chloride). Since the three model substances are among the most hygroscopic inorganic and organic compounds, these changes in RH represent upper limits on the uncertainty in the measured GF of the ambient particles, which are likely an internal mixture of more and less hygroscopic compounds, or on plume particles, which, as will be outlined, contained a large fraction of nonhygroscopic organics.

The SEMS, OPS, and APS each use a different operating principle to size aerosol particles. Total aerosol size distributions were created by merging the distributions over the nominal diameter range $0.01-20 \mu \mathrm{m}$ using an algorithm based on Khlystov et al. (2004). For the AMS data, a collection efficiency of 0.5 and a detection limit of $0.01 \mu \mathrm{g} \mathrm{m}^{-3}$ were applied. Total nonrefractory mass concentrations were calculated as the sum of organic and inorganic concentrations. Size distributions of the nonrefractory mass components were calculated from the AMS measurements (DeCarlo et al., 2004, 2006). Since the measured masses were close to the detection limit, the size distributions were smoothed over 11 size bins, resulting in a smoothed size distribution between 21 and $946 \mathrm{~nm}$. The AMS V-mode measurements were used to calculate the ratio of oxygen to carbon $(\mathrm{O}: \mathrm{C})$ in the measured organic particles (Aiken et al., 2007). For the WSOC measurements, the detection limit was $0.1 \mu \mathrm{g} \mathrm{C} \mathrm{m}^{-3}$. WSOC concentrations were converted into water-soluble organic matter (WSOM) concentrations using two different conversion factors based on literature values (Turpin and Lim, 2001): 1.4 for the R/V Point Sur organic plume, and 
1.8 for the marine background aerosol. Water-insoluble organic matter (WIOM) was calculated as the difference between AMS organic and WSOM. The FTIR functional group composition was determined using an automated algorithm that includes baselining, peak fitting, and integrating at specific wavenumbers associated with major carbon bond types (Russell et al., 2009; Takahama et al., 2012). The functional groups that were quantified include hydroxyl, alkane, amine, carbonyl, and carboxylic acid groups.

\subsection{Auxiliary data}

Three-day HYSPLIT back trajectories (Draxler and Rolph, 2012) ending at the ship's location and at an altitude of $50 \mathrm{~m}$ were calculated for every third hour of the R/V Point Sur cruise. GOES visible satellite images (every $15 \mathrm{~min}$ ) were collected and overlaid onto plots of the R/V Point Sur's course to confirm and complement the visual observations of clouds from the R/V Point Sur. To analyze synoptic weather conditions, maps of surface temperature, wind, pressure, and $500 \mathrm{mb}$ geopotential height were obtained from the website of the NOAA/OAR/ESRL Physical Science Division (http: //www.esrl.noaa.gov/psd/data/composites/day/).

\subsection{Synoptic conditions}

Synoptic conditions during the cruise were characterized by two different regimes, as determined by the $500 \mathrm{mb}$ geopotential height charts: the first ("Regime 1", 12-19 July) was governed by a midlatitude trough north of the cruise region; the second ("Regime 2", 20-23 July) was characterized by the reestablishment of a seasonally typical subtropical ridge to the south. Regime 1 was characterized by lower surface temperatures. HYSPLIT back trajectories show that during Regime 1, air masses arrived from the NW (Fig. 2). During the regime change (18-19 July), hereinafter termed "Transition", an episode of back trajectories from the west is apparent, in conjunction with a surface low-pressure center just north of the cruise area. Back trajectories parallel to the coast were dominant during Regime 2.

\subsection{Plume tracking}

During the majority of the cruise, ambient aerosol was measured. Background measurements are defined as time periods with CPC particle number concentrations $<1000 \mathrm{~cm}^{-3}$. On several occasions the R/V Point Sur turned into the freshly generated plume and tracked it downwind. Plume tracking was limited by the ship's maximum speed, which was slower than typical wind speeds on most days. The ship was able to catch up with and track the plume on three days $(16,17$, and 18 July, green shading in Fig. 3). The plume was tracked both by visually following the plume and by monitoring CPC particle number concentrations in real time. The ship's course was changed when needed to follow the highest concentrations. For this study, two plume tracking periods on 17 and

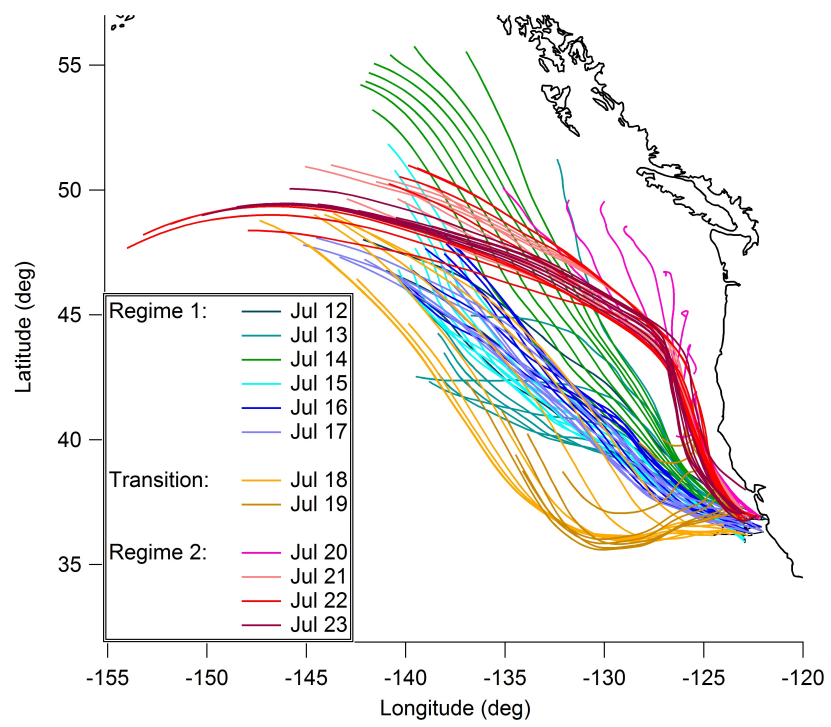

Fig. 2. Three-day HYSPLIT back trajectories (every three hours, ending altitude: $50 \mathrm{~m}$ ) show air mass origins during the cruise. Three distinct groups of trajectories governed by synoptic conditions are apparent: back trajectories pertaining to Regime 1 (blue, green), Transition (orange), and Regime 2 (red).

18 July were chosen for comparison. Plume characterization thus took place in air masses that were less influenced by coastal air (Regime 1 and Transition). The R/V Point Sur stack exhaust was sampled on one occasion on 22 July (yellow shading in Fig. 3).

During the cruise, 17 July was one of only two cloudfree days (Fig. 3, panel 3). GOES visible images show that clouds were present in the early morning but started to dissipate around 10:00 (this and all times hereinafter are local time, LT). The general area around the R/V Point Sur's location was cloud-free by 13:00. Relative humidity dropped from $91 \%$ around sunrise $(05: 54)$ to $80 \%$ at noon and further to an all-cruise minimum of $70 \%$ by $18: 00$. Ambient temperature in the same time frame ranged between 13.6 and $15.7^{\circ} \mathrm{C}$. Smoke production on the R/V Point Sur began at 6:45 and ended at 11:15. The wind direction measured on the R/V Point Sur during smoke production and tracking was between $300^{\circ}$ and $350^{\circ}$, with an average wind speed of $3.7 \pm 0.9 \mathrm{~m} \mathrm{~s}^{-1}$. The low wind speed on 17 July allowed for plume tracking by the R/V Point Sur for several hours. Figure $4 \mathrm{a}$ shows the ship's course as the plume was sampled. Smoke properties were measured during the time periods 11:20-11:32 (A1, fresh plume), 11:36-13:01 (A2, somewhat aged plume), and 15:02-15:20 (A3, aged plume). The plume was also encountered between 13:20 and 14:00, but it is likely that sampling occurred at the edge rather than the center of the plume. Therefore, this time period was not included in this analysis. The age of the plume encountered during tracking was estimated using the average wind speed and calculating the transport time from the location of the 
last smoke production to the ship's locations during the three time periods of plume sampling. This estimate of plume age represents a lower boundary as the smoke encountered at a particular point may have been produced at a time earlier than the last smoke production. The lower bounds of the plume ages during the three time periods of interest were estimated to be $\mathrm{A} 1 \approx 6 \mathrm{~min}, \mathrm{~A} 2 \approx 1.6 \mathrm{~h}$, and $\mathrm{A} 3 \approx 4.2 \mathrm{~h}$.

On 18 July, it remained cloudy throughout the day. In addition, thick fog was noted in the deck logs (the ship's fog horn was used) from 04:00 to noon. RH remained close to $100 \%$ during most of the morning and only dropped below $95 \%$ at $12: 25$. Ambient temperature ranged between 14.6 and $16.4{ }^{\circ} \mathrm{C}$. The R/V Point Sur's course during smoke sampling is shown in Fig. 4b. Smoke was produced in two stages, from 06:45 to 07:40 and again from 09:00 to 09:30. Intermittent smoke sampling at the plume's edge occurred between 06:15 and 08:30; see also Fig. 5b (B1). The center of the plume was tracked successfully between 09:35 and 10:45; see also Fig. 5b (B2). The typical wind speed during smoke production and plume tracking was $5.4 \pm 1.3 \mathrm{~m} \mathrm{~s}^{-1}$, with a direction between 190 and $240^{\circ}$. The estimated plume ages were $\mathrm{A} 1 \approx 2 \mathrm{~min}$ and $\mathrm{A} 2 \approx 37 \mathrm{~min}$.

During the plume tracking events (green shading in Fig. 3), the organic mass fraction (AMS organic mass: total AMS mass) in the fresh plume (plume age A1) was $\geq 97 \%$, as also found by Russell et al. (2013). The primary plume particles were created at a rate of $10^{11}-10^{13} \mathrm{~s}^{-1}$, and ranged between $100 \mathrm{~nm}$ and $8 \mu \mathrm{m}$ in diameter (Russell et al., 2013). The high organic mass fraction distinguished the plume from other cargo ship exhaust plumes, which typically contain $\sim 50 \%$ sulfate (Russell et al., 2013), and the background marine aerosol, which was found to contain between 40 and $60 \%$ organic. The average ratio of organic : sulfate mass encountered in the background aerosol was $1.15 \pm 0.80$, and exceeded 5.0 in only a couple measurements during the entire campaign. Therefore, the plume was identified through AMS measurements for which the ratio of organic: sulfate exceeded 5.0. R/V Point Sur stack emissions also had very high organic mass fractions (around 90-95\%), but were characterized by higher $\mathrm{BC}$ concentrations $\left(>6 \mathrm{ng} \mathrm{m}^{-3}\right)$ and lower overall mass concentrations (yellow shading in Fig. 3). Using BC as an indicator, we find that stack emissions influenced the plume measurements only on rare occasions. For both plume tracking events, the total volume concentrations of the plume during tracking (A2) were comparable (see also "large mode volume" in Fig. 9), suggesting that the attempt to track the center of the plume was successful.

\section{Results}

\subsection{Background aerosol}

AMS measurements show that the nonrefractory, submicrometer fraction of the background aerosol is dominated by sulfate and organics (Fig. 3). During Regime 1, wind speeds generally stayed below $10 \mathrm{~m} \mathrm{~s}^{-1}$. In Regime 2, wind speeds were frequently higher than $10 \mathrm{~m} \mathrm{~s}^{-1}$, but rarely exceeded $15 \mathrm{~m} \mathrm{~s}^{-1}$. Externally mixed sea salt starts to become an important contributor to marine aerosol at wind speeds exceeding 6-10 $\mathrm{m} \mathrm{s}^{-1}$ (Ovadnevaite et al., 2012; Swietlicki et al., 2008, and references therein). A mode of particle volume in the $400 \mathrm{~nm}-1 \mu \mathrm{m}$ range (Fig. 3, top panel) was observed during Regime 2 and likely had its origin in bubblebursting processes, but constituted only a minor contribution to the background aerosol. The plume measurements, which were conducted at low wind speeds during Regime 1, found that plume particle concentrations were much higher than the background particle concentrations. For these reasons, we do not expect sea salt to have a controlling influence on the plume measurements. BC concentrations during Regime 1 were lower $\left(1.03 \pm 1.06 \mathrm{ng} \mathrm{m}^{-3}\right)$ than during Regime $2\left(1.8 \pm 1.01 \mathrm{ng} \mathrm{m}^{-3}\right.$, the difference is statistically significant at the $99 \%$ confidence level), but short spikes in BC concentrations were observed in both regimes, confirming that the aerosol encountered during Regime 1 was still far from pristine. This is consistent with other work in the region showing a persistent influence of anthropogenic sources (Hegg et al., 2010; Coggon et al., 2012).

Hygroscopic growth factors at lower RH (40 and 70\%), below the deliquescence RH of most common inorganic salts, differed by meteorological regime. Table 2 shows that for a particle dry size of $150 \mathrm{~nm}$, the growth factors averaged over Regime 2 were significantly lower (95\% confidence level in a two-sample $z$ test) than those averaged over Regime 1. Hygroscopic growth at a RH below the deliquescence RH of most inorganic salts is at least partly enabled by the presence of organics (e.g., Hersey et al., 2009). It is unlikely that previous hygroscopic growth of inorganic components caused the observed growth as the aerosol was dried to $\mathrm{RH}<8 \%$ before the growth factor measurements, well below the efflorescence RH of most salts. The lower growth factors observed in Regime 2 at 40 and $70 \%$ RH could have been caused by the higher BC concentrations (if internally mixed) and/or by a lower organic mass fraction: the average submicrometer organic mass fraction was $0.53 \pm 0.11$ in Regime 1 and $0.35 \pm 0.10$ in Regime 2. Additionally, the organic fraction in Regime 1, with trajectories from the sea rather than from coastal regions, may have been more aged and therefore more hygroscopic. At a RH above the deliquescence of most pure salts (92 and $85 \%$ ), there was no significant difference in growth factors between Regimes 1 and 2. In previous studies, lower growth factors at high RH have been observed in continentally influenced air masses, 


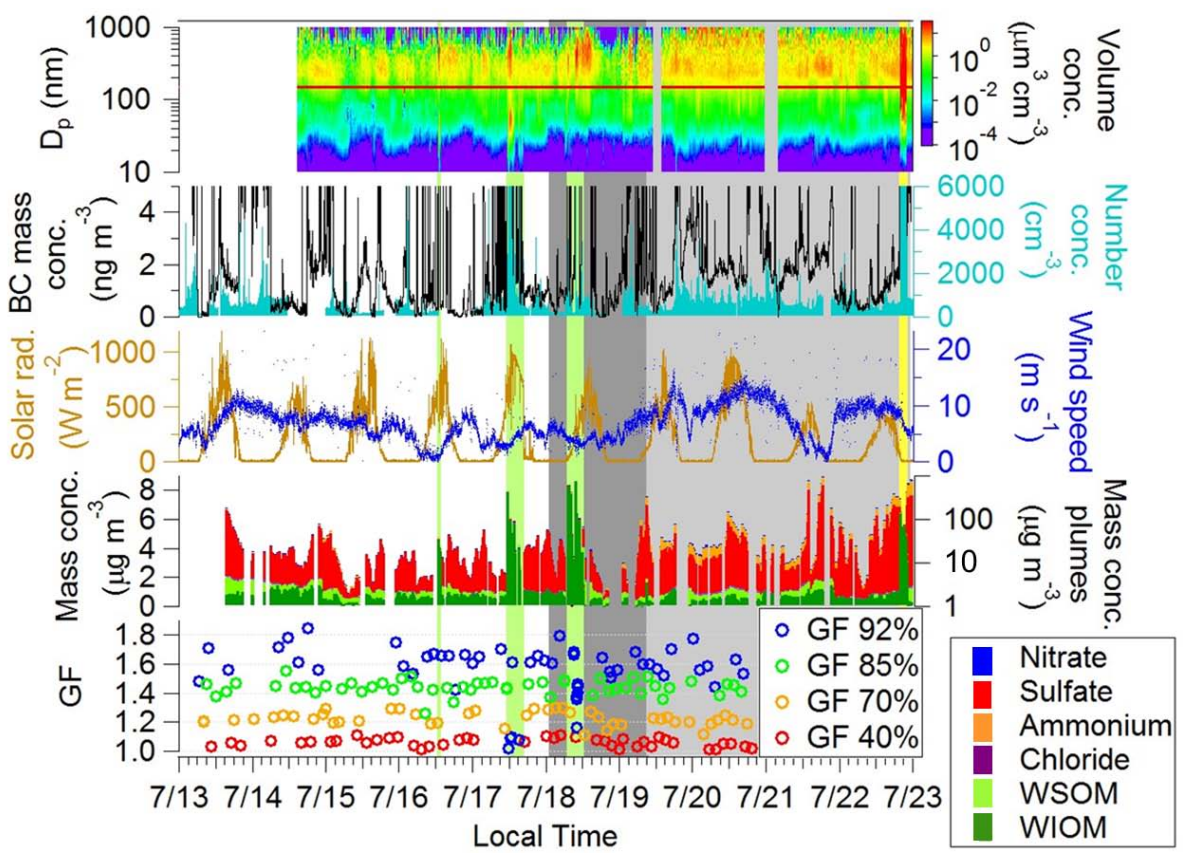

Fig. 3. Submicrometer volume distributions (SEMS), total number concentrations $<6000 \mathrm{~cm}^{-3}$ (CPC), black carbon concentrations $<5$ $\mathrm{ng} \mathrm{m}^{-3}$ (SP2), chemical composition (AMS and PILS), and hygroscopic growth factors (HTDMA) for a dry particle size of $150 \mathrm{~nm}$ (indicated in the volume distribution (top panel) by the red line) and four different RHs as a function of time over the entire research cruise. Green shading: plume; yellow shading: ship stack exhaust; no shading: Regime 1; dark-gray shading: Transition; light-gray shading: Regime 2. Mass concentrations for AMS and PILS in green or yellow shading (plumes) pertain to the right $y$ axis. Refer to Sect. 3.1 for more details.

referring to back trajectories originating over the continent (e.g., Massling et al., 2007; Allan et al., 2009; Hersey et al., 2009). This type of back trajectory was not encountered during this campaign (Fig. 2), explaining the lack of a more striking difference in growth factors by air mass origin at higher RH. Over the entire campaign, growth factors at $92 \% \mathrm{RH}$ (particle dry diameter of $150 \mathrm{~nm}$ ) ranged between 1.43 and 1.96 , with an average of $1.64 \pm 0.11$. These values compare well with the "more hygroscopic modes" observed in marine accumulation-mode aerosol in other studies (Massling et al., 2007; Swietlicki et al., 2008, and references therein; Allan et al., 2009; Mochida et al., 2011), and are associated with internally mixed aerosols containing sulfate, aged sea salt, and organic matter (Swietlicki et al., 2008). Higher growth factors are expected for fresh/pure sea-salt particles, and were found in the background aerosol of 18 July (Sect. 3.5).

\subsection{Secondary organic aerosol formation in the plume}

The most striking difference between the two plume tracking events (17 July, sunny, and 18 July, foggy) can be seen in the particle number concentrations in the aged plume (black/white marker boundaries in Fig. 4). On 18 July (Fig. 4b), number concentrations initially showed a short spike of $30000 \mathrm{~cm}^{-3}$, but dropped below $5000 \mathrm{~cm}^{-3}$ within five minutes and soon approached levels only about $40 \%$
Table 2. Hygroscopic growth factors ( $150 \mathrm{~nm}$ dry diameter) averaged over the two meteorological regimes. For the bold values, the difference of the means between Regime 1 and Regime 2 is statistically significant (95\% confidence level). " $\sigma$ " denotes standard deviations.

\begin{tabular}{lcc|cc}
\hline \multirow{2}{*}{$150 \mathrm{~nm}$} & \multicolumn{2}{c|}{ Regime 1 } & \multicolumn{2}{c}{ Regime 2 } \\
\cline { 2 - 5 } RH & mean & $\sigma$ & mean & $\sigma$ \\
\hline $40 \%$ & $\mathbf{1 . 0 6}$ & $\mathbf{0 . 0 3}$ & $\mathbf{1 . 0 4}$ & $\mathbf{0 . 0 3}$ \\
$70 \%$ & $\mathbf{1 . 2 4}$ & $\mathbf{0 . 0 4}$ & $\mathbf{1 . 2 1}$ & $\mathbf{0 . 0 3}$ \\
$85 \%$ & 1.44 & 0.05 & 1.44 & 0.05 \\
$92 \%$ & 1.66 & 0.12 & 1.60 & 0.10 \\
\hline
\end{tabular}

above the background. On 17 July (Fig. 4a), in contrast, particle number concentrations of $>10000 \mathrm{~cm}^{-3}$ (a lower limit, as the CPC has substantial coincidence errors at concentrations $>10000 \mathrm{~cm}^{-3}$ and does not report values exceeding $40000 \mathrm{~cm}^{-3}$ ) were observed for several hours at ages A2 and A3. These high particle concentrations, hours after the plume production stopped, are consistent with new particle formation successfully competing with dilution and coagulation. The temporal coincidence of these high number concentrations with the chemical signature of the plume (organic : sulfate > 5) and the absence of comparably high concentrations at any other time during the cruise make it highly 


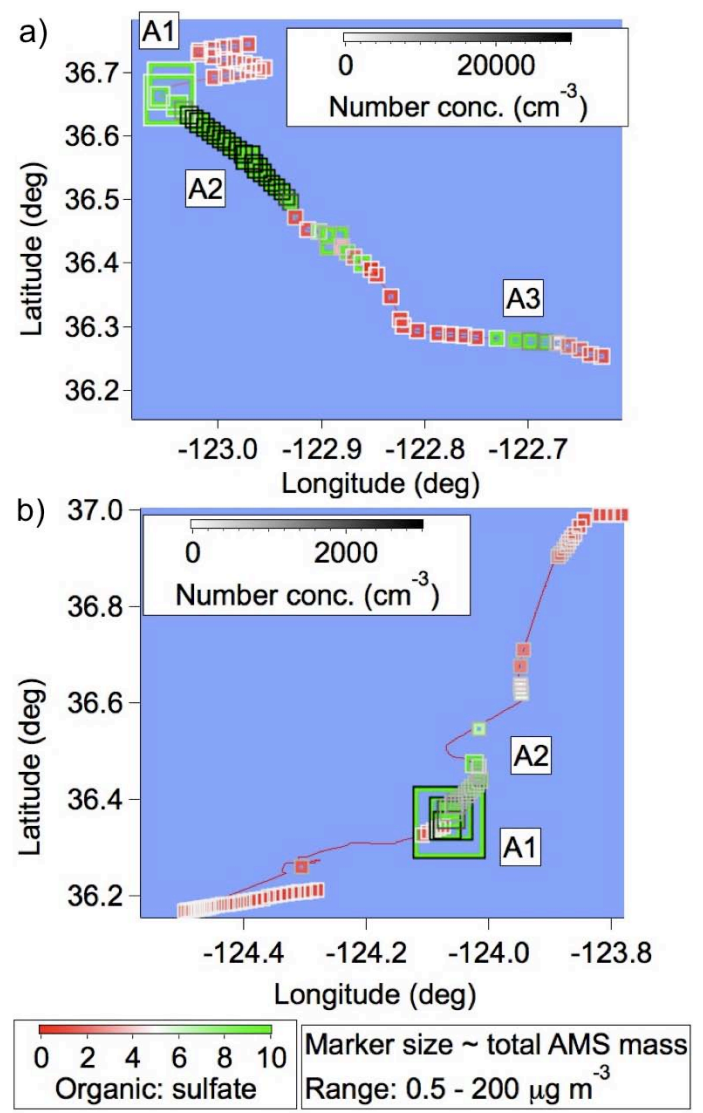

Fig. 4. R/V Point Sur ship trace during plume sampling on 17 July (a) and 18 July (b). The plume location is identified by values of organic: sulfate $>5$ (green markers). Black borders indicate high particle number concentrations. A1, A2, and A3 designate the three plume ages described in Sect. 2.6.

unlikely that the particles derived from any source other than the R/V Point Sur plume.

Figure 5 shows number and volume distributions for the plume events measured by the SEMS $(10-500 \mathrm{~nm})$ and the merged APS/OPS data $(500 \mathrm{~nm}-2 \mu \mathrm{m})$. On 17 July, a "banana plot" typical of new particle formation and subsequent growth is visible (Fig. 5a, age A2, 11:36 to 13:01). Volatile organic compounds (VOCs) were emitted in the gas phase, along with the primary particles from the generators, and may have condensed after dilution and cooling, or underwent oxidation to form SOA in the aging plume. Alternatively, VOCs may have evaporated from primary plume particles, and formed SOA after photooxidation, in a process similar to that shown in the laboratory chamber experiments by Robinson et al. (2007). Figure 5c shows initial plume particles in a size range of $500 \mathrm{~nm}-1 \mu \mathrm{m}$ approximately $5 \mathrm{~min}$ before the onset of new particle formation, and a subsequent decrease of both total volume and the modal size of the volume distribution, potentially indicating evaporation of plume particles.
A similar development potentially signifying evaporation of primary plume particles is also visible on 18 July (Fig. 5d). However, no new particle formation and growth was observed. It is conceivable that different parts of the plume with different particle size characteristics were sampled on the two days. Due to the reduced visibility on 18 July, it was difficult to follow the plume in an identical manner as on 17 July. The higher concentrations of large particles observed in the fresh plume on $18 \mathrm{July}$, as compared to the fresh plume on 17 July, indicate that a somewhat denser and fresher part of the plume was sampled initially. However, the plume was produced identically on both days, and, as described in Sect. 2.6, care was taken to follow the highest particle number concentrations. The most obvious difference distinguishing 18 July from 17 July was the presence of fog and clouds, and the associated diminished solar radiation (Fig. 3, middle panel). There are at least two explanations for the absence of a nucleation and growth event: (i) VOCs may have partitioned onto existing surfaces (e.g., fog droplets) instead of forming new particles - at least parts of the plume were able to enter the liquid phase, as evidenced by observations of the organic signature of the plume in cloud droplet residual particles (Shingler et al., 2012); and (ii) if photooxidation of plume VOCs was responsible for SOA formation on 17 July, cloud and fog shading may have suppressed such processes on 18 July.

\subsection{Chemical composition}

On 17 July (Fig. 6a), the maximum concentrations of AMS total organic mass and WSOM in the fresh plume (A1) were 885.67 and $4.16 \mu \mathrm{g} \mathrm{m}^{-3}$, respectively. The decrease of AMS organic mass with plume age is attributable to dilution as the ship moved farther away from the location of the last smoke production, and potentially also to evaporation of organic mass from primary plume particles (Sect. 3.2). An interesting aspect is the increase of absolute concentrations of WSOM during A2: from $3.44 \mu \mathrm{g} \mathrm{m}^{-3}$ at $11: 38$ to $4.96 \mu \mathrm{g} \mathrm{m}^{-3}$ at 12:32. Since the typical background WSOM concentrations were below $1 \mu \mathrm{g} \mathrm{m}^{-3}$, mixing of the plume with background aerosol cannot explain this increase. Rather, it is likely that WSOM formed in the plume, potentially contributing to the observed growth of newly formed particles. In the most aged part of the plume (A3), WSOM and AMS total organic concentrations still reached 3.4 and $48.4 \mu \mathrm{g} \mathrm{m}^{-3}$, respectively, showing that SOA production largely compensated for plume dilution.

On both days, the $\mathrm{O}: \mathrm{C}$ ratio and the relative contribution of WSOM to AMS total organic concentration increased as the plume aged, indicating a change in the functionality of the organic aerosol. Since the chemical measurements are mass based, the chemical composition data for plume age A1 are most representative of the larger, primary plume particles, which dominated the volume distribution (Fig. 5c, A1). The primary plume particles had low $\mathrm{O}: \mathrm{C}$ ratios $(<0.001)$ and few water-soluble components (WSOM: Org $\sim 0.002$ ) 

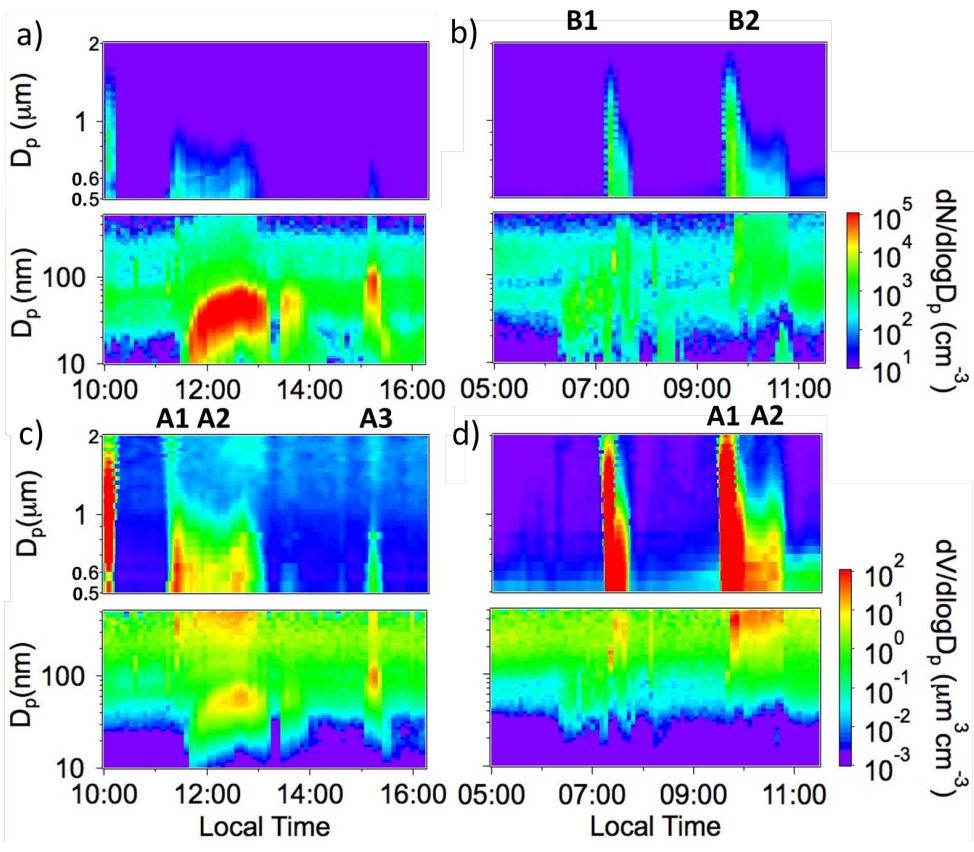

Fig. 5. Number (a, b) and volume (c, d) size distributions (SEMS and APS/OPS) of the plume particles on 17 July (a, c) and 18 July (b, d). A particle formation and growth event is observed on $17 \mathrm{July}$, which contributes substantial aerosol mass to the plume. Only large plume particles were detected on 18 July.

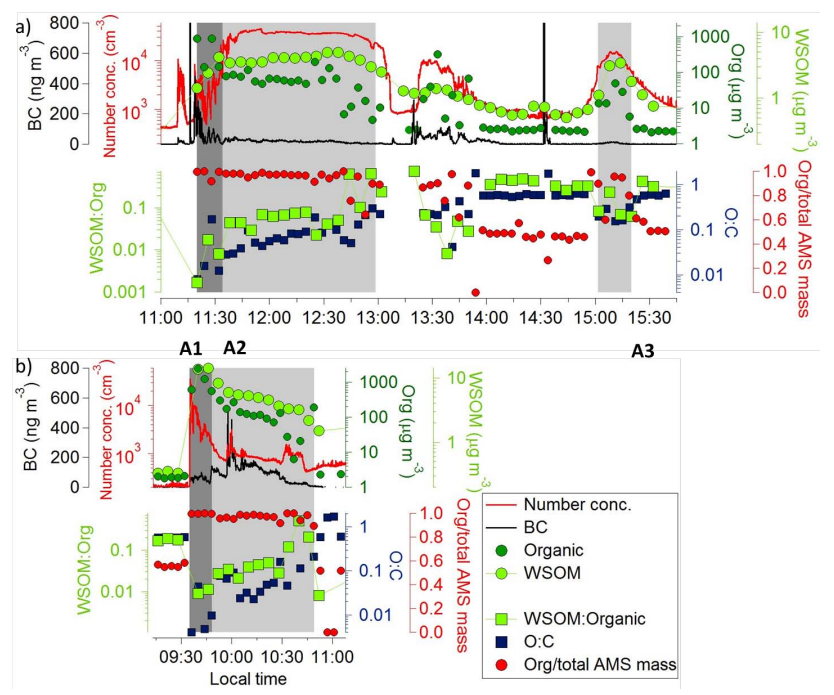

Fig. 6. Plume chemical composition measured by AMS for the three plume ages (A1, A2, A3) and marine background aerosol on 17 July (a) and 18 July (b). Light-gray shading designates plume ages A2 and $\mathrm{A} 3$, and dark-gray shading represents the fresh plume (A1). The ratios $\mathrm{O}: \mathrm{C}$ and WSOM : Org increase with plume age both days, and an absolute increase of WSOM is observed on 17 July.

(Fig. 6a, A1). At plume age A3, accumulation-mode particles, which likely had grown out of the nucleation mode, were dominant in the volume distribution (Fig. 5c, A3). Ratios of $\mathrm{O}: \mathrm{C}$ and WSOM : Org at A3 were approximately 0.2 and 0.07 , respectively (Fig. 6a, A3), showing that the organic fraction of the small-mode aerosol was more oxidized than that of the large mode. During A2, the volume was more evenly distributed over the primary and secondary plume particles (Fig. 5c, A2). For this plume age, it is not obvious whether the increasing $\mathrm{O}: \mathrm{C}$ ratio and the observed production of WSOM (Fig. 6a, A2) were mostly properties of the new, growing particles or a result of the aging of the primary particles, or both. On 18 July, new particle formation was not observed, and the volume distribution was at all times dominated by particles with diameters $>100 \mathrm{~nm}$ (Fig. 5d). An increase in $\mathrm{O}: \mathrm{C}$ and WSOM : Org was observed, suggesting that a chemical transformation to more oxidized and more water-soluble compounds occurred in the primary plume particles (Fig. 6b).

Figure 7 shows a comparison of the FTIR spectra of plume particles sampled during ages A1 and A2 ("A1+A2") on 17 and 18 July, and aged particles sampled during A3 on 17 July, as well as the spectrum of particles directly emitted from the ship stack. For comparison, the spectra of laboratory samples of the oil used for smoke generation and the diesel fuel for the ship's engine are shown as well. The spectra all show absorbance at $3000-2800 \mathrm{~cm}^{-1}$, which is indicative of alkane functional groups. The individual peaks at 2920 and $2850 \mathrm{~cm}^{-1}$ indicate the presence of methylene groups (Pavia et al., 2001). An increase in hydroxyl functional groups $\left(3700-3100 \mathrm{~cm}^{-1}\right)$ can be observed in the spectrum of the ship stack emissions (black line, upper panel, Fig. 7) compared to the laboratory spectrum of the ship diesel 


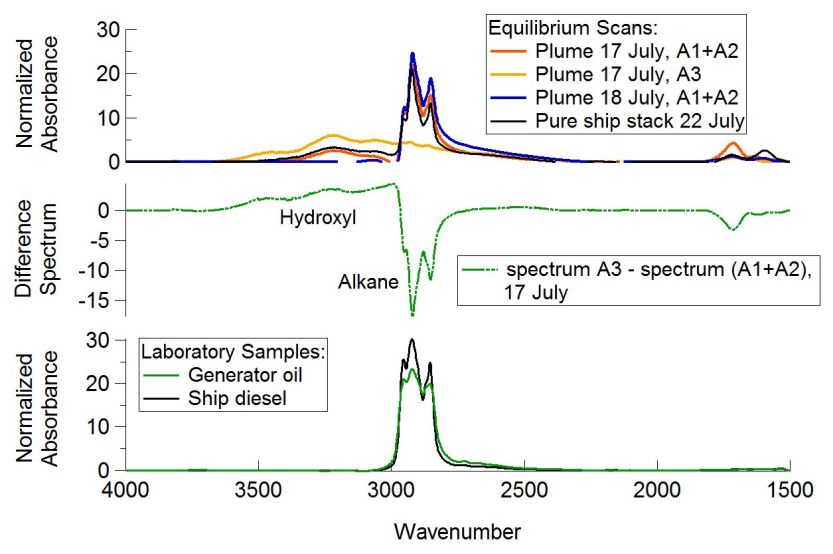

Fig. 7. FTIR spectra of the plume for a filter sample over ages A1 and A2 ("A1+A2"), and a sample for age A3 (upper panel) and their difference (middle panel). Spectra of the pure ship stack emissions (sampled on 22 July) as well as the smoke oil and the ship diesel fuel are shown for comparison (lower panel). Hydroxyl functional groups are detected in the aged smoke plume, but much less so in the fresh smoke and the laboratory samples.

(black line, lower panel, Fig. 7). Similarly, the spectra of the smoke plume (orange, yellow, and blue lines, upper panel, Fig. 7) show higher peaks in hydroxyl than the spectrum of the generator oil (green line, lower panel, Fig. 7). These relative increases in hydroxyl functional groups are indicative of oxidization of the alkane groups in the emissions that contributed to the particle formation. In the aged particles (A3) on $17 \mathrm{July}$, an increase in hydroxyl and a decrease in alkane functional groups are evident, implying increased oxidation with increased aging. This increase in hydroxyl functional groups with the age of particles is consistent with the increase in $\mathrm{O}: \mathrm{C}$ observed by the AMS. For plume age A3, the hydroxyl peaks are a large feature. The concurrent low ratios of WSOM : Org (0.07) reflect the fact that WSOM and hydroxyl groups are not directly correlated.

Size-resolved AMS measurements of organic mass (Fig. 8) clearly show the larger fresh plume mode in the size range $500-800 \mathrm{~nm}$ for both plume sampling events, the newly emerging particle mode at $\mathrm{A} 2$, and the grown particles at A3 on 17 July (Fig. 8a). The organic marker $m / z$ 57, which is associated with aliphatic organics $\left(\mathrm{C}_{4} \mathrm{H}_{9}^{+}\right)$and serves as a tracer for hydrocarbon-like organic aerosol (Zhang et al., 2005), was strongly related to the larger aerosol particles in the plume on both days, and did not appear in the smaller emerging mode. High-resolution AMS data show that $\mathrm{C}_{4} \mathrm{H}_{9}^{+}$ was the dominant fragment in $m / z 57$ in the fresh plume. The marker $m / z 44$, dominated by acid-like oxygenates, did not contribute substantially to any of the two modes. The organic marker $m / z 43$ was a component of both the larger and the smaller mode. Two fragments govern $m / z 43: \mathrm{C}_{3} \mathrm{H}_{7}^{+}$ from alkyl groups and $\mathrm{C}_{2} \mathrm{H}_{3} \mathrm{O}^{+}$from nonacid oxygenates ( $\mathrm{Ng}$ et al., 2011). In ambient aerosols, the organic marker

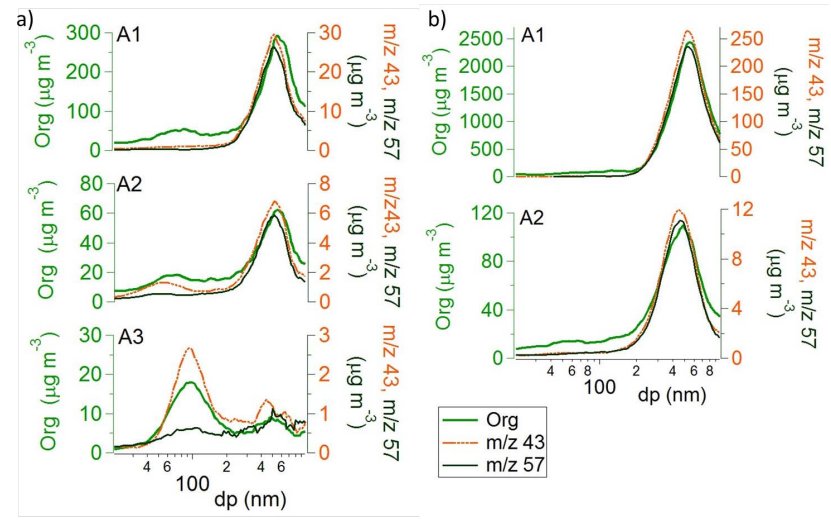

Fig. 8. Size-resolved concentrations of AMS organic, and the organic markers $m / z 57$ and $m / z 43$ for 17 July (a) and 18 July (b). The small particle mode is clearly visible on 17 July. The marker $m / z 57$ only appears in the large particle mode, the marker $m / z 43$ in both modes.

$\mathrm{m} / \mathrm{z} 43$ is expected to be dominated by nonacid oxygenates (Ng et al., 2010), which have also been found to be a major component in laboratory-generated SOA from primary anthropogenic sources (Heringa et al., 2012). When examining the temporal behavior of the fragments $\mathrm{C}_{2} \mathrm{H}_{3} \mathrm{O}^{+}$and $\mathrm{C}_{3} \mathrm{H}_{7}^{+}$ together with the integrated aerosol volumes for the small (particle diameter $<100 \mathrm{~nm}$ ) and the large (particle diameter $>100 \mathrm{~nm}$ ) mode (Fig. 9), it is obvious that on both days, $\mathrm{C}_{3} \mathrm{H}_{7}^{+}$traces the large-mode volume. $\mathrm{C}_{2} \mathrm{H}_{3} \mathrm{O}^{+}$, in contrast, traces the small particle volume on 17 July. The correlations between $\mathrm{C}_{3} \mathrm{H}_{7}^{+}$and the large mode are significant on both days, whereas $\mathrm{C}_{2} \mathrm{H}_{3} \mathrm{O}^{+}$only shows a significant correlation with the small-mode volume on 17 July (Table 3 ). This indicates that the small mode comprised more oxygenated compounds than the large mode.

\subsection{CCN concentrations}

The temporal development of CCN concentrations and activation ratios during the plume sampling periods is shown in Fig. 10. On both days, CCN concentrations at the lower supersaturation $(S)$ of $0.07-0.08 \%$ were largely unaffected by the presence of the plume. At medium $(0.24<S<0.26 \%)$ and high $(0.87<S<0.88 \%) S$, a substantial number of particles activated. Supersaturations in the stratocumulus deck are generally estimated to be in the range of 0.1-0.4\% (Hoppel et al., 1996; Feingold et al., 1998; Thouron et al., 2012). During E-PEACE, in-cloud supersaturations of 0.09 and 0.25 were estimated during two Twin Otter flights on 16 July and 10 August (Russell et al., 2013). As reported by Russell et al. (2013), the amount of CCN created in the plume was sufficient to create a track in the marine stratocumulus deck that was visible via satellite remote sensing. The primary plume particles were large enough to activate without the presence 
of soluble ions, but it is possible that some of the newly formed particles acted as $\mathrm{CCN}$ as well.

On 17 July (Fig. 10a), the onset of new particle formation at 11:32 was accompanied by a dramatic reduction in the activation ratio. The use of the $\mathrm{CCN}$ activation ratio as a proxy for hygroscopicity requires caution when there is a high variability in the aerosol size distribution, as was clearly the case here: the drop in activation ratio is a result of the order of magnitude increase in condensation nuclei $(\mathrm{CN})$ concentrations between $\mathrm{A} 1$ and $\mathrm{A} 2$. As the plume aged, $\mathrm{CCN}$ concentrations increased and eventually reached over $4000 \mathrm{~cm}^{-3}$ at high $S$. Changes in the size distribution are often the primary driver for CCN concentrations (Roberts et al., 2002; McFiggans et al., 2006), and probably explain most of the increase in the CCN concentrations at the high $S$ observed here: the newly formed particles were too small to act as $\mathrm{CCN}$, but grew into the relevant size ranges (Fig. 5a, A2, after 12:00) as the plume aged. However, as the primary plume particles were shown to become more oxidized, and therefore also more hygroscopic, it is likely that they contributed as well. At plume age $\mathrm{A} 3$, the secondary particles had grown into the accumulation mode (Fig. 5a), and CCN concentrations reached 637 and $9910 \mathrm{~cm}^{-3}$ at the medium and high $S$, respectively.

On 18 July (Fig. 10b), activation ratios were only initially suppressed, and increased steadily as $\mathrm{CN}$ concentrations decreased. The absolute $\mathrm{CCN}$ concentration at high $S$ increased with increasing plume age, from $151 \mathrm{~cm}^{-3}$ at $09: 33$ to a peak value of $424 \mathrm{~cm}^{-3}$ at 10:13, a far lower concentration than on 17 July. Since there was no such dramatic change in the size distribution as on $17 \mathrm{July}$, the increase in $\mathrm{CCN}$ concentration on 18 July was likely driven by chemical transformations and the condensation of hydrophilic organics on the existing particles. Very short aging times (no more than a few hours) to convert hydrophobic particles into $\mathrm{CCN}$ have been observed in laboratory experiments (Tritscher et al., 2011) and suggested for atmospheric particles, particularly in daytime conditions with photochemical production of secondary aerosol mass (Wang et al., 2010). The CCN activity at high supersaturations can also be explained without invoking organic transformation: even trace amounts of hygroscopic material (e.g., sulfate) deposited at the surface of the particle can lead to activation and droplet growth. Such inorganic trace components would be hard to detect by the mass-sensitive online chemical measurement methods.

The activation diameter for medium and high $S$ was estimated by integrating the merged APS/OPS and SEMS size distributions from the largest to smaller sizes to match the observed CCN concentrations. On 17 July, the estimated activation diameter $\left(d_{\mathrm{act}}\right)$ was smaller than the Kelvin diameter $\left(d_{\mathrm{K}}\right)$ at both supersaturations $\left(d_{\mathrm{K}}=0.81 \mu \mathrm{m}\right.$ for $S=0.26 \%$ and $\mathrm{d}_{\mathrm{K}}=0.24 \mu \mathrm{m}$ for $S=0.88 \%$ ) and at all plume ages. This implies that plume particles smaller than the Kelvin diameter activated due to the probable presence of soluble ions and a certain degree of hygroscopicity. On 18 July, the estimated activation diameter was larger than the Kelvin diam-
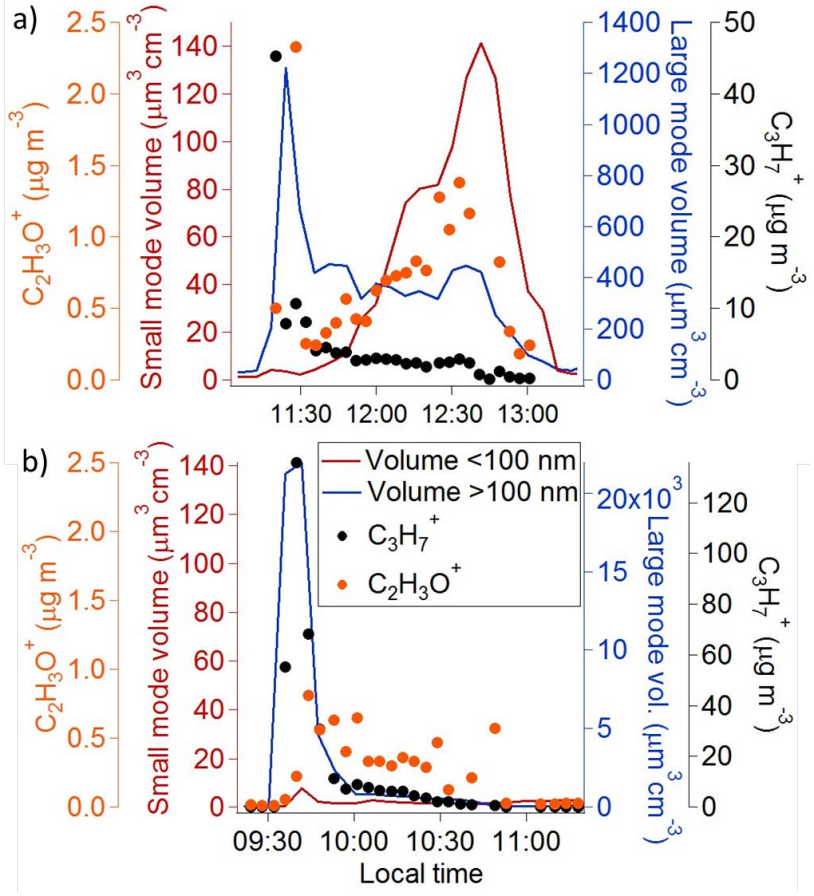

Fig. 9. Volume concentrations in the large (particle diameter $>100 \mathrm{~nm}$ ) and the small (particle diameter < $100 \mathrm{~nm}$ ) modes, and concentrations of $\mathrm{C}_{2} \mathrm{H}_{3} \mathrm{O}^{+}$and $\mathrm{C}_{3} \mathrm{H}_{7}^{+}$on 17 July (a) and 18 July (b). The large-mode volume concentration decreases with plume age on both days. On 17 July, the volume concentration in the small mode increases as the plume ages, while on 18 July, no such dramatic increase is observed. $\mathrm{C}_{2} \mathrm{H}_{3} \mathrm{O}^{+}$covaries with the small particle mode on 17 July, while $\mathrm{C}_{3} \mathrm{H}_{7}^{+}$covaries with the large particle volume on both days.

eter for both supersaturations at age A1. For medium $S, d_{\text {act }}$ was lower than $d_{\mathrm{K}}$ at plume age A2; for high $S, d_{\text {act }}$ stayed above $d_{\mathrm{K}}$. An activation diameter larger than the Kelvin diameter can occur if a subpopulation of particles does not activate even at high $S$. Instances of $d_{\mathrm{act}}>d_{\mathrm{K}}$ thus point to the presence of an external mixture (Burkart et al., 2012). As discussed in Sect. 3.2, a fresher part of the plume was likely sampled on 18 July. Thus, the external mixture may comprise both large plume particles that did not activate and more aged plume particles, that activated at a size below $d_{\mathrm{K}}$. Bulk measurements of $\mathrm{CCN}$ are prone to uncertainties in externally mixed aerosols; thus, future work should aim to measure size-resolved $\mathrm{CCN}$ concentrations. A decreasing trend in estimated $d_{\text {act }}$ was observed at both supersaturations and on both days, and is indicative of a chemical transformation of $\mathrm{CCN}$-inactive to $\mathrm{CCN}$-active particles (e.g., Furutani et al., 2008)

\subsection{Hygroscopic growth factors}

As opposed to the $\mathrm{CCN}$ measurements, which were not size resolved, the GFs were measured for specific sizes, thus 
Table 3. Correlations ( $a=$ intercept; $b=$ slope; $n=$ number of samples) between the fragments $\mathrm{C}_{2} \mathrm{H}_{3} \mathrm{O}^{+}$and $\mathrm{C}_{3} \mathrm{H}_{7}^{+}$and particle volume for the large and the small mode. Bold: correlation is statistically significant at the $99 \%$ level. $\mathrm{C}_{3} \mathrm{H}_{7}^{+}$correlates with the large mode on both days $\mathrm{C}_{2} \mathrm{H}_{3} \mathrm{O}^{+}$correlates with the small mode on 17 July.

\begin{tabular}{llrrrr|rrrrr}
\hline \multirow{2}{*}{ Day } & Mode & \multicolumn{4}{c}{$\mathrm{C}_{3} \mathrm{H}_{7}^{+}$} & \multicolumn{4}{c}{$\mathrm{C}_{2} \mathrm{H}_{3} \mathrm{O}^{+}$} \\
\cline { 3 - 10 } & & $a$ & $b$ & $r^{2}$ & $n$ & $a$ & $b$ & $r^{2}$ & $n$ \\
\hline \multirow{2}{*}{ 17 July } & volume $>100 \mathrm{~nm}$ & $\mathbf{- 0 . 4 5 9}$ & $\mathbf{0 . 0 0 9}$ & $\mathbf{0 . 7 7}$ & $\mathbf{2 4}$ & 0.270 & 0.001 & 0.16 & 22 \\
& volume $<100 \mathrm{~nm}$ & 2.881 & -0.016 & 0.10 & 24 & $\mathbf{0 . 2 4 7}$ & $\mathbf{0 . 0 0 6}$ & $\mathbf{0 . 3 9}$ & $\mathbf{2 2}$ \\
\hline \multirow{2}{*}{ 18 July } & volume $>100 \mathrm{~nm}$ & $\mathbf{1 . 5 2 5}$ & $\mathbf{0 . 0 0 3}$ & $\mathbf{0 . 8 6}$ & $\mathbf{4 2}$ & 0.247 & 1.418 & 0.01 & 41 \\
& volume $<100 \mathrm{~nm}$ & 3.765 & 0.859 & 0.03 & 42 & 0.275 & -0.003 & 0.00 & 41 \\
\hline
\end{tabular}

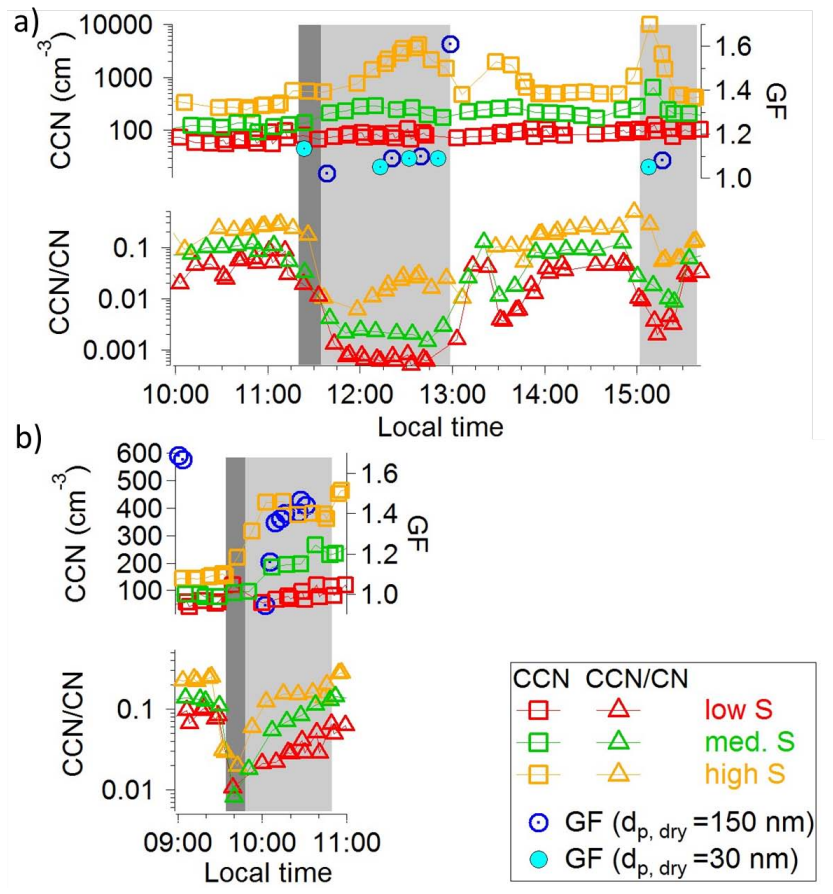

Fig. 10. Hygroscopic growth factors for 30 and $150 \mathrm{~nm}$ dry size at $92 \% \mathrm{RH}$, and time series of $\mathrm{CCN}$ concentrations and activation ratios at three supersaturations: $0.07<S<0.08 \%$ (red, low), $0.24<S<0.26 \%$ (green, medium), and $0.87<S<0.88 \%$ (yellow, high) for the plume sampling events on 17 July (a) and 18 July (b). Dark-gray shading represents plume age A1, and lightgray shading plume ages A2 and A3. Refer to Sect. 3.4 for more details.

giving direct insight into the hygroscopic properties of the smaller and the larger mode particles. The bulk chemical composition measurements cannot be assumed to be representative of the chemical composition of smaller particle sizes $(30,75$, and $150 \mathrm{~nm})$, for which the hygroscopic growth factors were measured.

Hygroscopic growth factors in the plume on 17 July at age A2 and A3 (Fig. 10a) were very low: for particles with a dry size of $30 \mathrm{~nm}$ (representative of the newly formed particles),
GFs $(\mathrm{RH}=92 \%)$ ranged between 1.05 and 1.09 . Those with a dry size of $150 \mathrm{~nm}$ (representative of larger plume particles) had GFs between 1.02 and 1.10. The high GFs shown at the very beginning and the very end of the plume period are representative of background marine aerosol, as evidenced by low number concentrations in the respective GF distributions (about a factor of 2 lower than those observed within the plume). Particles with a dry size of $75 \mathrm{~nm}$ did not grow at any plume age. The $75 \mathrm{~nm}$ particles are representative of the particles contributing most to the $\mathrm{CCN}$ concentrations, as the particle number concentration in the plume at ages A2 and $\mathrm{A} 3$ was dominated by particles in the size range below $100 \mathrm{~nm}$ (Fig. 5a). The very low to negligible GFs are not in contradiction with the observed increase in $\mathrm{CCN}$ concentrations: trace amounts of inorganic compounds contribute little to hygroscopic growth, which is sensitive to volume fractions of hygroscopic material. Similarly, insoluble but wettable organic substances would result in little or no hygroscopic growth, while allowing for activation as $\mathrm{CCN}$.

While the measured GF change (1-1.1) is within the upper estimate of GF measurement uncertainty based on sodium chloride given in Sect. 2.3, the measured O:C ratios and GFs compare well with a chamber study on aging diesel exhaust, in which $\mathrm{O}: \mathrm{C}$ ratios were observed to increase from 0.1 to 0.19 within $<2 \mathrm{~h}$, while simultaneously, GFs increased from 1 to 1.1 (95\% RH, $100 \mathrm{~nm}$ dry particle diameter) (Tritscher et al., 2011). The organic aerosol formed in the plume underwent an overall chemical transformation leading to higher $\mathrm{O}: \mathrm{C}$ ratios, from $<0.001$ in the fresh plume to values around 0.2 in the plume at age A3 (Fig. 6a). Additionally, sizeresolved measurements of the AMS organic concentrations at the center of the two modes of the plume (the primary mode at 500-800 nm and the emerging mode of $\sim 100 \mathrm{~nm}$ at plume age A3) indicate that a more oxygenated form of organic aerosol was present in the growing small mode as compared to the large primary mode (Sect. 3.3), potentially giving rise to modest hygroscopic growth.

On 18 July, in contrast, GFs increased significantly with increasing plume age (Fig. 10b). For particles with a dry size of 30 and $75 \mathrm{~nm}$, the GF distributions (not shown) were bimodal, showing a mode with negligible hygroscopic growth 
and a background mode with GFs between 1.5 and 1.7. For $150 \mathrm{~nm}$ particles, the GF distributions were mono-modal, but very broad, suggesting the presence of several overlapping peaks that are not readily distinguishable. In order to gain more insight, the distributions were approximated with a fit of three lognormal modes. In the background aerosol (i.e., an average over all scans of 18 July that were uninfluenced by local particle sources), two higher GF modes were found and yielded GFs of 1.60 and 2.09. One of these modes (GF $=1.60$ ) corresponds to the "more hygroscopic mode" of the marine background (Sect. 3.1), the other ( $\mathrm{GF}=2.09)$ potentially to a pure sea-salt mode (Swietlicki et al., 2008). These two modes were assumed to be present and invariant throughout plume sampling. With this constraint, a lognormal mode was fitted that best explained the remainder of the GF distribution. This mode was still wider than the GF distributions for plume particles observed on $17 \mathrm{July}$, and thus the possibilities that additional modes were present, or that the background during plume tracking may differ from the all-day average, cannot be excluded. The GFs shown in the gray-shaded area in Fig. 10b pertain to the modeled lower GF mode. Within eight consecutive scans, the GF increased from 0.94 to 1.47 , a much larger increase than on 17 July. While these GF values seem to approach background values, it has to be noted that number concentrations in all GF scans were at least 36\% higher than those in background GF distributions, and organic mass fractions were above $91 \%$ (Fig. 6b), thus sampling occurred well within the plume.

$\mathrm{O}: \mathrm{C}$ and WSOM : Org increases for 18 July are comparable to those of 17 July and do not explain the range of GFs (up to 1.47). Based on the findings of Jimenez et al. (2009), for a purely organic particle, an $\mathrm{O}: \mathrm{C}$ ratio of $0.55-0.6$ is required to result in a GF of 1.5. Such levels were not reached during plume sampling in this study. However, in the absence of a newly emerging mode, mass concentrations below about $200 \mathrm{~nm}$ were very low. Bulk chemical measurements may not be representative of particles with a $150 \mathrm{~nm}$ dry size, and size-resolved AMS measurements close to the detection limit are less reliable. We suggest the following explanations for the increasing GF on 18 July: (i) internal mixing with inorganic compounds, in particular sulfate. On 17 July, the $150 \mathrm{~nm}$ particles likely grew out of smaller particles through condensation of VOCs (assuming higher VOC levels on the sunny than on the foggy day), and may therefore have contained higher organic mass fractions than those on 18 July. (ii) Aqueous-phase processing of organics towards more hygroscopic organic species, as has been documented before in the region (e.g., Crahan et al., 2004; Sorooshian et al., 2007). The expected higher $\mathrm{O}: \mathrm{C}$ ratios resulting from aqueous-phase processing may not be reflected in the bulk measurement of $\mathrm{O}: \mathrm{C}$, for the reasons stated above. Filter samples show that two particulate species that are tracers for cloud-processing the region (Crahan et al., 2004; Sorooshian et al., 2007) were observed in $\mathrm{PM}_{10}$ samples of the smoke on 18 July but not on 17 July: oxalate $\left(236 \mathrm{ng} \mathrm{m}^{-3}\right)$ and gly- oxylate $\left(79 \mathrm{ng} \mathrm{m}^{-3}\right)$. Oxalate is also associated with coarse crustal matter (e.g., Wang et al., 2012); however, its simultaneous detection with glyoxylate only on 18 July suggests that aqueous-phase processing was an important factor on that day. Another, more speculative explanation is that surface organic films may have prevented water uptake on 17 July and formed a kinetic barrier, which may have been "broken" by the higher RH on 18 July. However, the timescales over which such a barrier would operate are not known (McFiggans et al., 2006).

\section{Conclusions}

We have shown substantial differences in hygroscopic growth and $\mathrm{CCN}$ activity of smoke-generated organic particles emitted in the marine atmosphere under different meteorological conditions. In sunny conditions, new particle formation occurred and originated from VOCs emitted together with or evaporated from larger primary plume particles. The organic fragment $m / z 43$ appeared both in the large plume particles and in the newly emerging mode, but with differing dominant fragments: $\mathrm{C}_{3} \mathrm{H}_{7}^{+}$(alkyl groups) was dominant in the large particle mode, while $\mathrm{C}_{2} \mathrm{H}_{3} \mathrm{O}^{+}$(nonacid oxygenates) was dominant in the smaller mode, showing that the newly formed particles consisted of more oxygenated organic compounds. No growth of newly formed particles was observed in the aged plume in foggy conditions. Most likely, photooxidation of plume VOCs leading to new particle formation was less efficient due to the reduced solar flux. Additionally, the fog droplets may have acted as a sink for VOCs and small particles due to the large surface area they provide for diffusive deposition.

Meteorological conditions have a profound impact on size distributions and $\mathrm{CCN}$ yield of the plume particles. The majority of the plume particles did not act as CCN. However, the newly formed particles activated as $\mathrm{CCN}$ initially after growing into the appropriate size ranges and $\mathrm{CCN}$ concentrations reached very high numbers $\left(>4000 \mathrm{~cm}^{-3}\right)$ at high supersaturations ( $S=0.8 \%$ ). Newly formed particles, consisting largely of SOA, can thus provide high concentrations of CCN, as was found in other studies (Hennigan et al., 2012). In the foggy conditions without new particle formation, the number concentration of $\mathrm{CCN}$ produced by the plume was lower by an order of magnitude.

In sunny conditions, plume particles with a dry size of 30 and $150 \mathrm{~nm}$ showed very limited hygroscopic growth (GF $=1.02-1.10$ at $\mathrm{RH}=92 \%$ ), while those with a dry size of $75 \mathrm{~nm}$ did not grow at all. Mixing with inorganic components, or aging of the organic fraction, which was reflected in increasing ratios of O:C and WSOM:Org, can cause hygroscopic growth. While the increase in $\mathrm{O}: \mathrm{C}$ from $<0.001$ to $\sim 0.2$ is below what has been observed to influence GFs in ambient organic aerosols (Jimenez et al., 2009), both the range of $\mathrm{O}: \mathrm{C}$ and that of GFs are consistent with a 
chamber study of aging primary organic aerosol (Tritscher et al., 2011). This shows that the aging time to transform a pure hydrocarbon-like aerosol of the kind emitted in this experiment into a hygroscopic organic aerosol of the kind found in many ambient measurements is longer than the $1-4 \mathrm{~h}$ that were available in this study in clean marine conditions. The aging time for the same particles to act as $\mathrm{CCN}$, in contrast, is much shorter $(<1 \mathrm{~h})$. On the foggy day, GFs of $150 \mathrm{~nm}$ particles increased to up to 1.47 as the plume aged. A different degree of internal mixing with hygroscopic inorganic compounds and/or aqueous-phase processing are suggested as possible explanations for this behavior.

Acknowledgements. This work was funded by ONR grants N00014-11-1-0783, N00014-10-1-0200, and N00014-10-1-0811, and NSF grants AGS-1013381, AGS-10131423, and AGS1008848. The measurements at sea were made possible by the support of the R/V Point Sur crew and staff. We acknowledge NOAA/OAR/ESRL PSD, Boulder, Colorado, USA, for providing weather maps from their website at http://www.esrl.noaa.gov/psd/. The authors gratefully acknowledge the NOAA Air Resources Laboratory (ARL) for the provision of the HYSPLIT transport and dispersion model and READY website (http://ready.arl.noaa.gov) used in this publication. Regina Hitzenberger is acknowledged for helpful comments and suggestions.

Edited by: M. C. Facchini

\section{References}

Aiken, A. C., DeCarlo, P. F., and Jimenez, J. L.: Elemental analysis of organic species with electron ionization highresolution mass spectrometry, Anal. Chem., 79, 8350-8358, doi:10.1021/ac071150w, 2007.

Allan, J. D., Topping, D. O., Good, N., Irwin, M., Flynn, M., Williams, P. I., Coe, H., Baker, A. R., Martino, M., Niedermeier, N., Wiedensohler, A., Lehmann, S., Müller, K., Herrmann, H., and McFiggans, G.: Composition and properties of atmospheric particles in the eastern Atlantic and impacts on gas phase uptake rates, Atmos. Chem. Phys., 9, 9299-9314, doi:10.5194/acp9-9299-2009, 2009.

Bateman, A. P., Nizkorodov, S. A., Laskin, J., and Laskin, A.: Photolytic processing of secondary organic aerosols dissolved in cloud droplets, Phys. Chem. Chem. Phys., 13, 12199-12212, doi:10.1039/c1cp20526a, 2011.

Blando, J. D. and Turpin, B. J.: Secondary organic aerosol formation in cloud and fog droplets: a literature evaluation of plausibility, Atmos. Environ., 34, 1623-1632, doi:10.1016/S13522310(99)00392-1, 2000.

Brechtel, F. J. and Kreidenweis, S. M.: Predicting Particle Critical Supersaturation from Hygroscopic Growth Measurements in the Humidified TDMA. Part I: Theory and Sensitivity Studies, J. Atmos. Sci. 57, 1854-1871, doi:10.1175/15200469(2000)057<1854:PPCSFH>2.0.CO;2, 2000a.

Brechtel, F. J. and Kreidenweis, S. M.: Predicting Particle Critical Supersaturation from Hygroscopic Growth Measurements in the Humidified TDMA. Part II: Laboratory and Ambi- ent Studies, J. Atmos. Sci. 57, 1872-1887, doi:10.1175/15200469(2000)057<1872:PPCSFH>2.0.CO;2, 2000 b.

Burkart, J., Hitzenberger, R., Reischl, G., Bauer, H., Leder, K., and Puxbaum, H.: Activation of "synthetic ambient" aerosols - Relation to chemical composition of particles $<100 \mathrm{~nm}$, Atmos. Environ., 54, 583-591, doi:10.1016/j.atmosenv.2012.01.063, 2012.

Cavalli, F., Facchini, M. C., Decesari, S., Mircea, M., Emblico, L., Fuzzi, S., Ceburnis, D., Yoon, Y. J., O’Dowd, C. D., Putaud, J.-P., and Dell'Acqua, A.: Advances in characterization of size-resolved organic matter in marine aerosol over the North Atlantic, J. Geophys. Res., 109, D24215, doi:10.1029/2004JD005137, 2004.

Coggon, M. M., Sorooshian, A., Wang, Z., Metcalf, A. R., Frossard, A. A., Lin, J. J., Craven, J. S., Nenes, A., Jonsson, H. H., Russell, L. M., Flagan, R. C., and Seinfeld, J. H.: Ship impacts on the marine atmosphere: insights into the contribution of shipping emissions to the properties of marine aerosol and clouds, Atmos. Chem. Phys., 12, 8439-8458, doi:10.5194/acp-12-84392012, 2012.

Crahan, K. K., Hegg, D., Covert, D. S., and Jonsson, H.: An exploration of aqueous oxalic acid production in the coastal marine atmosphere, Atmos. Environ., 38, 3757-3764, doi:10.1016/j.atmosenv.2004.04.009, 2004.

Dall'Osto, M., Ceburnis, D., Monahan, C., Worsnop, D. R., Bialek, J., Kulmala, M., Kurtén, T., Ehn, M., Wenger, J., Sodeau, J., Healy, R., and O'Dowd, C.: Nitrogenated and aliphatic organic vapors as possible drivers for marine secondary organic aerosol growth, J. Geophys. Res., 117, D12311, doi:10.1029/2012JD017522, 2012.

DeCarlo, P. F., Slowik, J. G., Worsnop, D. R., Davidovits, P., and Jimenez, J. L.: Particle morphology and density characterization by combined mobility and aerodynamic diameter measurements. Part 1: Theory, Aerosol Sci. Technol., 38, 1180-1205, doi:10.1080/027868290903907, 2004.

DeCarlo, P. F., Kimmel,J. R., Trimborn, A., Northway, M. J., Jayne, J. T., Aiken, A. C., Gonin, M., Fuhrer, K., Horvath, T., Docherty, K. S., Worsnop, D. R., and Jimenez, J. L.: Field-deployable, high-resolution, time-of-flight aerosol mass spectrometer, Anal. Chem., 78, 8281-8289, doi:10.1021/ac061249n, 2006.

de Gouw, J., Middlebrook, A. M., Warneke, C., Ahmadov, R., Atlas, E. L., Bahreini, R., Blake, D. R., Brock, C. A., Brioude, J., Fahey, D. W., Fehsenfeld, F. C., Holloway, J. S., Le Henaff, M., Lueb, R. A., McKeen, S. A., Meagher, J. F., Murphy, D. M., Paris, C., Parrish, D. D., Perring, A. E., Pollack, I. B., Ravishankara, A. R., Robinson, A. L., Ryerson, T. B., Schwarz, J. P., Spackman, J. R., Srinivasan, A., and Watts, L. A.: Organic aerosol formation downwind from the Deepwater Horizon oil spill, Science, 331, 1295-1299, doi:10.1126/science.1200320, 2011.

Dick, W. D., Saxena, P., and McMurry, P. H.: Estimation of water uptake by organic compounds in submicron aerosols measured during the Southeastern Aerosol and Visibility Study, J. Geophys. Res., 105, 1471-1479, doi:10.1029/1999JD901001, 2000.

Draxler, R. R. and Rolph, G. D.: HYSPLIT (HYbrid SingleParticle Lagrangian Integrated Trajectory) Model, access via NOAA ARL READY Website, available at: http://ready.arl.noaa.gov/HYSPLIT.php (last access: August 2012), NOAA Air Resources Laboratory, Silver Spring, MD, 2012. 
Duplissy, J., DeCarlo, P. F., Dommen, J., Alfarra, M. R., Metzger, A., Barmpadimos, I., Prevot, A. S. H., Weingartner, E., Tritscher, T., Gysel, M., Aiken, A. C., Jimenez, J. L., Canagaratna, M. R., Worsnop, D. R., Collins, D. R., Tomlinson, J., and Baltensperger, U.: Relating hygroscopicity and composition of organic aerosol particulate matter, Atmos. Chem. Phys., 11, 11551165, doi:10.5194/acp-11-1155-2011, 2011.

Dusek, U., Frank, G. P., Massling, A., Zeromskiene, K., Iinuma, Y., Schmid, O., Helas, G., Hennig, T., Wiedensohler, A., and Andreae, M. O.: Water uptake by biomass burning aerosol at suband supersaturated conditions: closure studies and implications for the role of organics, Atmos. Chem. Phys., 11, 9519-9532, doi:10.5194/acp-11-9519-2011, 2011.

El Haddad, I., Yao Liu, Nieto-Gligorovski, L., Michaud, V., Temime-Roussel, B., Quivet, E., Marchand, N., Sellegri, K., and Monod, A.: In-cloud processes of methacrolein under simulated conditions - Part 2: Formation of secondary organic aerosol, Atmos. Chem. Phys., 9, 5107-5117, doi:10.5194/acp-9-5107-2009, 2009.

Ervens, B., Turpin, B. J., and Weber, R. J.: Secondary organic aerosol formation in cloud droplets and aqueous particles (aqSOA): a review of laboratory, field and model studies, Atmos. Chem. Phys., 11, 11069-11102, doi:10.5194/acp-1111069-2011, 2011.

Eyring, V., Isaksen, I. S. A., Berntsen, T., Collins, W. J., Corbett, J. J., Endresen, O., Grainger, R. G., Moldanova, J., Schlager, H., and Stevenson, D. S.: Transport impacts on atmosphere and climate: shipping, Atmos. Environ., 44, 4735-4771, doi:10.1016/j.atmosenv.2009.04.059, 2009.

Facchini, M. C., Rinaldi, M., Decesari, S., Carbone, C., Finessi, E., Mircea, M., Fuzzi, S., Ceburnis, Flanagan, R., Nilsson, E. D., de Leeuw, G. D., Martino, M., Woeltjen, J., and O'Dowd, C.: Primary submicron marine aerosol dominated by insoluble organic colloids and aggregates, Geophys. Res. Lett., 35, L17814, doi:10.1029/2008GL034210, 2008a.

Facchini, M. C., Decesari, S., Rinaldi, M., Carbone, C., Finessi, E., Mircea, M., Fuzzi, S., Moretti, F., Tagliavini, E., Ceburnis, D., and O'Dowd, C.: Important source of marine secondary organic aerosol from biogenic amines, Environ. Sci. Technol., 42, 91169121, doi:10.1021/es8018385, 2008b.

Feingold G., Walko, R. L., Stevens, B., and Cotton, W. R.: Simulations of marine stratocumulus using a new microphysical parameterization scheme, Atmos. Res., 47-48, 505-528, doi:10.1016/S0169-8095(98)00058-1, 1998.

Frossard, A. A. and Russell, L. M.: Removal of sea salt hydrate water from seawater-derived samples by dehydration, Environ. Sci. Technol., 46, 13326-13333, doi:10.1021/es3032083, 2012.

Furutani, H., Dall'Osto, M., Roberts, G. C., and Prather, K. A.: Assessment of the relative importance of atmospheric aging on CCN activity derived from field observations, Atmos. Environ., 42, 3130-3142, doi:10.1016/j.atmosenv.2007.09.024, 2008.

Gantt, B. and Meskhidze, N.: The physical and chemical characteristics of marine primary organic aerosol: a review, Atmos. Chem. Phys., 13, 3979-3996, doi:10.5194/acp-13-3979-2013, 2013.

George, I. J., Vlasenko, A., Slowik, J. G., Broekhuizen, K., and Abbatt, J. P. D.: Heterogeneous oxidation of saturated organic aerosols by hydroxyl radicals: uptake kinetics, condensed-phase products, and particle size change, Atmos. Chem. Phys., 7, 41874201, doi:10.5194/acp-7-4187-2007, 2007.
Gysel, M., McFiggans, G. B., and Coe, H.: Inversion of tandem differential mobility analyser (TDMA) measurements, J. Aerosol Sci., 40, 134-151, doi:10.1016/j.jaerosci.2008.07.013, 2009.

Hawkins, L. N., Russell, L. M., Covert, D. S., Quinn, P. K., and Bates, T. S.: Carboxylic acids, sulfates and organosulfates in processed continental organic aerosol over the Southern Pacific Ocean during VOCALS-Rex 2008, J. Geophys. Res., 115, D13201, doi:10.1029/2009JD013276, 2010.

Hegg, D. A.: The importance of liquid phase oxidation of $\mathrm{SO}_{2}$ in the atmosphere, J. Geophys. Res., 90, 3773-3779, doi:10.1029/JD090iD02p03773, 1985.

Hegg, D. A., Covert, D. S., Jonsson, H. H., and Woods, R. K.: The contribution of anthropogenic aerosols to aerosol light-scattering and CCN activity in the California coastal zone, Atmos. Chem Phys., 10, 7341-7351, doi:10.5194/acp-10-7341-2010, 2010.

Hennigan, C. J., Westervelt, D. M., Riipinen, I., Engelhart, G. J., Lee, T., Collett, J. L., Pandis, S. N., Adams, P. J., and Robinson, A. L.: New particle formation and growth in biomass burning plumes: An important source of cloud condensation nuclei, Geophys. Res. Lett., 39, L09805, doi:10.1029/2012GL050930, 2012.

Heringa, M. F., DeCarlo, P. F., Chirico, R., Tritscher, T., Clairotte, M., Mohr, C., Crippa, M., Slowik, J. G., Pfaffenberger, L., Dommen, J., Weingartner, E., Prévôt, A. S. H., and Baltensperger, U.: A new method to discriminate secondary organic aerosols from different sources using high-resolution aerosol mass spectra, Atmos. Chem. Phys., 12, 2189-2203, doi:10.5194/acp-122189-2012, 2012.

Hersey, S. P., Sorooshian, A., Murphy, S. M., Flagan, R. C., and Seinfeld, J. H.: Aerosol hygroscopicity in the marine atmosphere: a closure study using high-time-resolution, multiple-RH DASHSP and size-resolved C-ToF-AMS data, Atmos. Chem. Phys., 9, 2543-2554, doi:10.5194/acp-9-2543-2009, 2009.

Hersey, S. P., Craven, J. S., Metcalf, A. R., Lin, J., Lathem, T., Suski, K., Cahill, J., Duong, H., Sorooshian, A., Jonsson, H. H., Nenes, A., Prather, K. A., Flagan, R. C., and Seinfeld, J. H.: Composition and Hygroscopicity of the Los Angeles Aerosol: CalNex, J. Geophys. Res., 118, 3016-3036, 2013.

Hoppel W. A., Frick, G. M., and Fitzgerald, J. W.: Deducing droplet concentration and supersaturation in marine boundary layer clouds from surface aerosol measurements, J. Geophys. Res., 101, 26553-26565, doi:10.1029/96JD02243, 1996.

Jimenez, J. L., Canagaratna, M. R., Donahue, N. M., Prevot, A. S. H., Zhang, Q., Kroll, J. H., DeCarlo, P. F., Allan, J. D., Coe, H., Ng, N. L., Aiken, A. C., Docherty, K. S., Ulbrich, I. M., Grieshop, A. P., Robinson, A. L., Duplissy, J., Smith, J. D., Wilson, K. R., Lanz, V. A., Hueglin, C., Sun, Y. L.,. Tian, J, Laaksonen, A., Raatikainen, T., Rautiainen, J., Vaattovaara, P., Ehn, M., Kulmala, M., Tomlinson, J. M., Collins, D. R., Cubison, M. J., Dunlea, E. J., Huffman, J. A., Onasch, T. B., Alfarra, M. R., Williams, P. I., Bower, K., Kondo, Y., Schneider, J., Drewnick, F., Borrmann, S., Weimer, S., Demerjian, K., Salcedo, D., Cottrell, L., Griffin, R., Takami, A., Miyoshi, T., Hatakeyama, S., Shimono, A., Sun, J. Y., Zhang, Y. M., Dzepina, K., Kimmel, J. R., Sueper, D., Jayne, J. T., Herndon, S. C., Trimborn, A. M., Williams, L. R., Wood, E. C., Middlebrook, A. M., Kolb, C. E., Baltensperger, U., and Worsnop, D. R.: Evolution of organic aerosols in the atmosphere, Science, 326, 1525-1529, doi:10.1126/science.1180353, 2009. 
Khlystov A., Stanier, C., and Pandis, S. N.: An algorithm for combining electrical mobility and aerodynamic size distributions data when measuring ambient aerosol, Aerosol Sci. Technol., 38, 229-238, doi:10.1080/02786820390229543, 2004.

Leck, C. and Bigg, E. K.: Source and evolution of the marine aerosol-A new perspective, Geophys. Res. Lett., 32, L19803, doi:10.1029/2005GL023651, 2005.

Massling, A., Leinert, S., Wiedensohler, A., and Covert, D.: Hygroscopic growth of sub-micrometer and one-micrometer aerosol particles measured during ACE-Asia, Atmos. Chem. Phys., 7, 3249-3259, doi:10.5194/acp-7-3249-2007, 2007.

Massoli, P., Lambe, A.T., Ahern, A. T., Williams, L. R., Ehn, M., Mikkilä, J., Canagaratna, M. R., Brune, W. H., Onasch, T. B., Jayne, J. T., Petäjä, T., Kulmala, M., Laaksonen, A., Kolb, C. E., Davidovits, P., and Worsnop, D. R.: Relationship between aerosol oxidation level and hygroscopic properies of laboratory generated secondary organic aerosol (SOA) particles, Geophys. Res. Lett., 37, L24801, doi:10.1029/2010GL045258, 2010.

McFiggans, G., Artaxo, P., Baltensperger, U., Coe, H., Facchini, M. C., Feingold, G., Fuzzi, S., Gysel, M., Laaksonen, A., Lohmann, U., Mentel, T. F., Murphy, D. M., O’Dowd, C. D., Snider, J. R., and Weingartner, E.: The effect of physical and chemical aerosol properties on warm cloud droplet activation, Atmos. Chem. Phys., 6, 2593-2649, doi:10.5194/acp-6-2593-2006, 2006.

Meskhidze, N. and Nenes, A.: Phytoplankton and cloudiness in the Southern Ocean, Science, 314, 1419, doi:10.1126/science.1131779, 2006.

Meyer, N. K., Duplissy, J., Gysel, M., Metzger, A., Dommen, J., Weingartner, E., Alfarra, M. R., Prevot, A. S. H., Fletcher, C., Good, N., McFiggans, G., Jonsson, A. M., Hallquist, M., Baltensperger, U., and Ristovski, Z. D.: Analysis of the hygroscopic and volatile properties of ammonium sulphate seeded and unseeded SOA particles, Atmos. Chem. Phys., 9, 721-732, doi:10.5194/acp-9-721-2009, 2009.

Middlebrook, A. M., Murphy, D. M., and Thomson, D. S.: Observations of organic material in individual marine particles at Cape Grim during the First Aerosol Characterization Experiment (ACE 1), J. Geophys. Res., 103, 16475-16483, doi:10.1029/97JD03719, 1998.

Mochida, M., Nishita-Hara, C., Furutani, H., Miyazaki, Y., Jung, J., Kawamura, K., and Uematsu, M.: Hygroscopicity and cloud condensation nucleus activity of marine particles over the western North Pacific, J. Geophys. Res., 116, D06204, doi:10.1029/2010JD014759, 2011.

Modini, R. L., Harris, B., and Ristovski, Z. D.: The organic fraction of bubble-generated, accumulation mode Sea Spray Aerosol (SSA), Atmos. Chem. Phys., 10, 2867-2877, doi:10.5194/acp10-2867-2010, 2010.

Moore, R. H., Raatikainen, T., Langridge, J. M., Bahreini, R., Brock, C. A., Holloway, J. S., Lack, D. A., Middlebrook, A. M., Perring, A. E., Schwarz, J. P., Spackman, J. R., and Nenes, A.: CCN spectra, hygroscopicity, and droplet activation kinetics of secondary organic aerosol resulting from the 2010 Deepwater Horizon oil spill, Environ. Sci. Technol., 46, 3093-3100, doi:10.1021/es203362w, 2012.

Murphy, S. M., Agrawal, H., Sorooshian, A., Padro, L. T., Gates, H., Hersey, S., Welch, W. A., Jung, H., Miller, J. W., Cocker, D. R., Nenes, A., Jonsson, H. H., Flagan, R. C., and Seinfeld, J. H.: Comprehensive simultaneous shipboard and airborne characteri- zation of exhaust from a modern container ship at sea, Environ. Sci. Technol., 43, 4626-4640, doi:10.1021/es802413j, 2009.

Ng, N. L., Canagaratna, M. R., Zhang, Q., Jimenez, J. L., Tian, J., Ulbrich, I. M., Kroll, J. H., Docherty, K. S., Chhabra, P. S., Bahreini, R., Murphy, S. M., Seinfeld, J. H., Hildebrandt, L., Donahue, N. M., DeCarlo, P. F., Lanz, V. A., Prévôt, A. S. H., Dinar, E., Rudich, Y., and Worsnop, D. R.: Organic aerosol components observed in Northern Hemispheric datasets from Aerosol Mass Spectrometry, Atmos. Chem. Phys., 10, 46254641, doi:10.5194/acp-10-4625-2010, 2010.

Ng, N. L., Canagaratna, M. R., Jimenez, J. L., Chhabra, P. S., Seinfeld, J. H., and Worsnop, D. R.: Changes in organic aerosol composition with aging inferred from aerosol mass spectra, Atmos. Chem. Phys., 11, 6465-6474, doi:10.5194/acp-11-64652011, 2011.

O'Dowd, C. D. and de Leeuw, G.: Marine aerosol production: a review of the current knowledge, Philos. Trans. R. Soc. A, 365, 1753-1774, doi:10.1098/rsta.2007.2043, 2007.

O’Dowd, C. D., Maria Cristina Facchini, M. C., Cavalli, F., Ceburnis, D., Mircea, M., Decesari, S., Fuzzi, S., Yoon Y. J., and Putaud, J.-P.: Biogenically driven organic contribution to marine aerosol, Nature, 431, 676-680, doi:10.1038/nature02959, 2004.

Ovadnevaite, J., Ceburnis, D., Martucci, G., Bialek, J., Monahan, C., Rinaldi, M., Facchini, M. C., Berresheim, H., Worsnop, D. R., and O'Dowd, C.: Primary marine organic aerosol: A dichotomy of low hygroscopicity and high CCN activity, Geophys. Res. Lett., 38, L21806, doi:10.1029/2011GL048869, 2011 a.

Ovadnevaite, J., O’Dowd, C., Dall'Osto, M., Ceburnis, D., Worsnop, D. R., and Berresheim, H.: Detecting high contributions of primary marine organic matter to marine aerosol: A case study, Geophys. Res. Lett., 38, L02807, doi:10.1029/2010GL046083, 2011 b.

Ovadnevaite, J., Ceburnis, D., Canagaratna, M., Berresheim, H., Bialek, J., Martucci, G, Worsnop, D., and O'Dowd, C.: On the effect of wind speed on submicron sea salt mass concentrations and source fluxes, J. Geophys. Res., 117, D16201, doi:10.1029/2011JD017379, 2012.

Pavia, D. L., Lapman, G. M., and Kriz, G. S.: Introduction to spectroscopy, Third Ed., Brooks/Cole, 2001.

Petters, M. D. and Kreidenweis, S. M.: A single parameter representation of hygroscopic growth and cloud condensation nucleus activity, Atmos. Chem. Phys., 7, 1961-1971, doi:10.5194/acp-71961-2007, 2007.

Petters, M. D., Carrico, C. M., Kreidenweis, S. M., Prenni, A. J., DeMott, P. J., Collett, J. L., and Moosmuller, H.: Cloud condensation nucleation activity of biomass burning aerosol, J. Geophys. Res., 114, D22205, doi:10.1029/2009JD012353, 2009.

Roberts, G. C. and Nenes, A.: A continuous-flow streamwise thermal-gradient $\mathrm{CCN}$ chamber for atmospheric measurements, Aerosol Sci. Technol., 39, 206-221, doi:10.1080/027868290913988, 2005.

Roberts, G. C., Artaxo, P., Zhou, J. C., Swietlicki, E., and Andreae, M. O.: Sensitivity of CCN spectra on chemical and physical properties of aerosol: A case study from the Amazon basin, J. Geophys. Res., 114, doi:10.1029/2001JD000583, 2002.

Robinson, A. L., Donahue, N. M., Shrivastava, M. K., Weitkamp, E. A., Sage, A. M., Grieshop, A. P., Lane, T. E., Pierce, J. R., and Pandis, S. N.: Rethinking organic aerosols: semivolatile emissions and photochemical aging, Science, 315, 1259, 
doi:10.1126/science.1133061, 2007.

Russell, L. M., Takahama, S. Liu, S., Hawkins, L. N., Covert, D. S., Quinn, P. K., and Bates, T. S.: Oxygenated fraction and mass of organic aerosol from direct emission and atmospheric processing measured on the R/V Ronald Brown during TEXAQS/GoMACCS 2006, J. Geophys. Res., 114, doi:10.1029/2008jd011275, 2009.

Russell, L. M., Hawkins, L. N., Frossard, A. A., Quinn, P. K., and Bates, T. S.: Carbohydrate-like composition of submicron atmospheric particles and their production from ocean bubble bursting, P. Natl. Acad. Sci. USA, 107, 15, 6652-6657, doi:10.1073/pnas.0908905107, 2010.

Russell, L. M., Sorooshian, A., Seinfeld, J. H., Albrecht, B. A., Nenes, A., Ahlm, L., Chen, Y. C., Coggon, M., Craven, J. S., Flagan, R. C., Frossard, A. A., Jonsson, H., Jung, E., Lin, J. J., Metcalf, A. R., Modini, R., Mülmenstädt, J., Roberts, G. C., Shingler, T., Song, S., Wang, Z., and Wonaschütz, A.: Eastern Pacific Emitted Aerosol Cloud Experiment (E-PEACE), B. Am. Meteorol. Soc., 94, 709-729, doi:10.1175/BAMS-D-12-00015, 2013.

Saxena, P., Hildemann, L., McMurry, P. H., and Seinfeld, J. H.: Organics alter hygroscopic behavior of atmospheric particles, J. Geophys. Res., 100, 18755-18770, doi:10.1029/95JD01835, 1995.

Shingler, T., Dey, S., Sorooshian, A., Brechtel, F. J., Wang, Z., Metcalf, A., Coggon, M., Mülmenstädt, J., Russell, L. M., Jonsson, H. H., and Seinfeld, J. H.: Characterisation and airborne deployment of a new counterflow virtual impactor inlet, Atmos. Meas. Tech., 5, 1259-1269, doi:10.5194/amt-5-1259-2012, 2012.

Sorooshian, A., Lu, M.-L., Brechtel, F. J., Jonsson, H., Feingold, G., Flagan, R. C., and Seinfeld, J. H., On the source of organic acid aerosol layers above clouds, Environ. Sci. Technol., 41, 46474654, doi:10.1021/es0630442, 2007.

Sorooshian, A., Hersey, S., Brechtel, F. J., Corless, A., Flagan, R. C., and Seinfeld, J. H.: Rapid, Size-Resolved Aerosol Hygroscopic Growth Measurements: Differential Aerosol Sizing and Hygroscopicity Spectrometer Probe (DASH-SP), Aerosol Sci. Technol. 42, 445-464, doi:10.1080/02786820802178506, 2008.

Sorooshian, A., Murphy, S. M., Hersey, S., Bahreini, R., Jonsson, H., Flagan, R. C., and Seinfeld, J. H.: Constraining the contribution of organic acids and AMS m/z 44 to the organic aerosol budget: On the importance of meteorology, aerosol hygroscopicity, and region, Geophys. Res. Lett., 37, L21807, doi:10.1029/2010GL044951, 2010.

Sorooshian, A., Csavina, J., Shingler, T., Dey, S., Brechtel, F., Sáez, E., and Betterton, E. A.: Hygroscopic and chemical properties of aerosols collected near a copper smelter: Implications for public and environmental health, Environ. Sci. Technol., 46, 94739480, doi:10.1021/es302275k, 2012.

Stolzenburg, M.: An ultra-fine aerosol size distribution measuring system, Ph.D. Thesis, University of Minnesota, Minneapolis, 1988.

Sullivan, A. P., Peltier, R. E., Brock, C. A., de Gouw, J. A, Holloway, J. S., Warneke, C., Wollny, A. G., and Weber, R. J.: Airborne measurements of carbonaceous aerosol soluble in water over northeastern united states: Method development and an investigation into water-soluble organic carbon sources, J. Geophys. Res., 111, D23S46, doi:10.1029/2006jd007072, 2006.

Swietlicki, E., Hansson, H.-C., Hämeri, K., Svenningsson, B., Massling, A., McFiggans, G., McMurry, P. H., Petäja, T., Tunved,
P., Gysel, M., Topping, D., Weingartner, E., Baltensperger, U., Rissler, J., Wiedensohler, A., and Kulmala, M.: Hygroscopic properties of submicrometer atmospheric aerosol particles measured with H-TDMA instruments in various environments - a review, Tellus, 60B, 432-469, doi:10.1111/j.16000889.2008.00350.x, 2008.

Takahama, S., Johnson, A., and Russell, L. M.: Quantification of carboxylic and carbonyl functional groups in organic aerosol infrared absorbance spectra, Aerosol Sci. Technol., 47, 310-325, doi:10.1080/02786826.2012.752065, 2012.

Thouron, O., Brenguier, J.-L., and Burnet, F.: Supersaturation calculation in large eddy simulation models for prediction of the droplet number concentration, Geosci. Model Dev., 5, 761-772, doi:10.5194/gmd-5-761-2012, 2012.

Tritscher T., Juranyi, Z., Martin, M., Chirico, R., Gysel, M., Heringa, M. F., deCarlo, P. F., Sierau, B., Prevot, A. S. H., Weingartner, E., and Baltensperger, U.: Changes of hygroscopicity and morphology during ageing of diesel soot, Environ. Res. Lett., 6, 034026, doi:10.1088/1748-9326/6/3/034026, 2011.

Turpin, B. J. and Lim, H.-J: Species contributions to $\mathrm{PM}_{2.5}$ mass concentrations: Revisiting common assumptions for estimating organic mass, Aerosol Sci. Technol., 35, 602-610, doi:10.1080/02786820152051454, 2001.

Wang, G., Kawamura, K., Cheng, C., Li, J., Cao, J., Zhang, R., Zhang, T., Liu, S., and Zhao, Z.: Molecular distribution and stable carbon isotopic composition of dicarboxylic acids, ketocarboxylic acids, and $\alpha$-dicarbonyls in size-resolved atmospheric particles from Xi‘an City, China, Environ. Sci. Technol., 46, 4783-4791, doi:10.1021/es204322c, 2012.

Wang, J., Cubison, M. J., Aiken, A. C., Jimenez, J. L., and Collins, D. R.: The importance of aerosol mixing state and size-resolved composition on $\mathrm{CCN}$ concentration and the variation of the importance with atmospheric aging of aerosols, Atmos. Chem. Phys., 10, 7267-7283, doi:10.5194/acp-10-7267-2010, 2010.

Wex, H., Stratmann, F., Hennig, T., Hartmann, S., Niedermeier, D., Nilsson, E., Ocskay, R., Rose, D., Salma, I., and Ziese, M.: Connecting hygroscopic growth at high humidities to cloud activation for different particle types, Environ. Res. Lett., 3035004 doi:10.1088/1748-9326/3/3/035004, 2008.

Wex, H., Petters, M. D., Carrico, C. M., Hallbauer, E., Massling, A., McMeeking, G. R., Poulain, L., Wu, Z., Kreidenweis, S. M., and Stratmann, F.: Towards closing the gap between hygroscopic growth and activation for secondary organic aerosol: Part $1-$ Evidence from measurements, Atmos. Chem. Phys., 9, 3987-3997, doi:10.5194/acp-9-3987-2009, 2009.

Wonaschütz, A., Hersey, S. P., Sorooshian, A., Craven, J. S., Metcalf, A. R., Flagan, R. C., and Seinfeld, J. H.: Impact of a large wildfire on water-soluble organic aerosol in a major urban area: the 2009 Station Fire in Los Angeles County, Atmos. Chem. Phys., 11, 8257-8270, doi:10.5194/acp-11-8257-2011, 2011.

Zhang Q., Alfarra, M. R., Worsnop, D. R., Allan, J. D., Doe, H., Canagaratna, M., and Jimenez, J. L.: Deconvolution and quantification of hydrocarbon-like and oxygenated organic aerosols based on aerosol mass spectrometry, Environ. Sci. Technol., 39, 4938-4952, doi:10.1021/es0485681, 2005. 